\title{
Verifying the State of Financing Constraints: Evidence from U.S. Business Credit Contracts*
}

\author{
Ralf R. Meisenzahl \\ Federal Reserve Board
}

November 14, 2011

\begin{abstract}
Many policy makers are concerned that tight financing constraints for small businesses are stalling the recovery from the Great Recession. This paper empirically assesses two agency problems commonly used to motivate financing constraints - one resulting in a "firm balance sheet channel" and one resulting in a "bank balance sheet channel." Evaluating specific models of these two agency problems against a comprehensive data set of U.S. small business credit contracts, I find strong support for the firm balance sheet channel but only little support for the bank balance sheet channel. A complementary regression analysis confirms this result. Hence, to support small business lending, policies seeking to improve firms' balance sheets may be more effective than providing additional capital to banks.
\end{abstract}

JEL Codes: E44, E50, G20

Keywords: agency cost, agency models of financing constraints, firm balance sheet channel, bank balance sheet channel, credit contracts, small business lending, costly state verification

*E-mail: ralf.r.meisenzahl@frb.gov. Mailing address: Mailstop 153, 20th and C Streets NW, Washington, DC 20551. Telephone: +1 202912 7997. An earlier version of this paper was circulated as "Financing Constraints and Investment: Evidence from U.S. Business Credit Contracts." I would like to thank Ing-Haw Chen, Larry Christiano, Rochelle Edge, Martin Eichenbaum, Diana Hancock, Joel Mokyr, Dale Mortensen, Skander Van den Heuvel and seminar participants at CREI, Chicago FED, Rochester, IMF, Federal Reserve Board, Northwestern University, 2011 Financial Intermediation Research Society Meeting, and University of Mainz for helpful comments. All errors are mine. The views stated are those of the author and do not necessarily reflect those of the Board of Governors of the Federal Reserve System. 


\begin{abstract}
Many policy makers are concerned that tight financing constraints for small businesses are stalling the recovery from the Great Recession. This paper empirically assesses two agency problems commonly used to motivate financing constraints - one resulting in a "firm balance sheet channel" and one resulting in a "bank balance sheet channel." Evaluating specific models of these two agency problems against a comprehensive data set of U.S. small business credit contracts, I find strong support for the firm balance sheet channel but only little support for the bank balance sheet channel. A complementary regression analysis confirms this result. Hence, to support small business lending, policies seeking to improve firms' balance sheets may be more effective than providing additional capital to banks.
\end{abstract}




\section{Introduction}

The lack of improvement in credit availability to small businesses in the recovery following the Great Recession has been a major concern for policymakers. ${ }^{1}$ Part of the reason for this concern is that while small, these businesses account for about one-half of U.S. GDP, and they contribute largely to job creation and fluctuations in unemployment (Haltiwanger, Jarmin, and Miranda, 2010). In the eyes of many policymakers, the reduction of small business credit availability has impaired the ability of small businesses to create jobs. ${ }^{2}$ Hence, for a robust recovery to gain traction in the small-business sector, a number of policies have been enacted to help improve small-business credit availability. For instance, the Small Business Jobs Act of 2010 created the $\$ 30$ billion Small Business Lending Fund (SBLF). The effectiveness of the various policies being proposed depends on whether these policies can overcome the type of financial friction that actually limits the ability of small businesses to borrow. In particular, many policies provide capital to banks. In some cases like the SBLF, this capital provision includes specific incentives for banks to boost small business lending. However, the effectiveness of such policies may be limited if financial frictions arising at the firm level are the key constraint for financing small business investment and hiring.

The literature frequently uses two specific strategies for modeling financial frictions that limit credit available to firms. The first strategy is an agency problem borrower and lender, which results in a "firm balance sheet channel" (Bernanke and Gertler, 1989). The second strategy is an agency problem between banks and its depositors and bond holders, which then results in a "bank balance sheet channel." Two specific models that include such agency problems between participants in the credit intermediation process are the costly state verification model (CSV) of Townsend (1979) and the moral hazard in monitoring model (MH) of Holmström and Tirole (1997). ${ }^{3}$ These two models, however, have many differences between them. The most obvious is that there is only one agency problem - one between the borrower (entrepreneur) and the lender (bank) - and therefore only a firm balance sheet channel in the CSV model. But there are two agency problems - one between the entrepreneur and the bank and one between the bank and the bank's depositors and bond holders and therefore a firm balance sheet channel and a bank balance sheet channel in the MH model. ${ }^{4}$

\footnotetext{
${ }^{1}$ In a speech given on April 14, 2011, Federal Reserve Governor Duke summarizes concerns about small business lending, http://www.federalreserve.gov/newsevents/speech/duke20110414a.htm. Federal Reserve Chairman Bernanke reiterated concerns about tight credit in this Semiannual Monetary Policy Report to the Congress on July 13, 2011, http://www.federalreserve.gov/newsevents/testimony/bernanke20110713a.htm.

${ }^{2}$ An increase in credit market frictions can feed back into the labor market, resulting in higher (steady state) unemployment (Wasmer and Weill, 2004).

${ }^{3}$ Hart and Moore (1994) and Kiyotaki and Moore (1997) also include an agency problem between borrowers and lenders but emphasize ex post moral hazard/limited enforcement. Stiglitz and Weiss (1981) present a model of credit rationing as a result of sorting and incentives to take on risk.

${ }^{4}$ There are also slight differences between the CSV and MH model in terms of how they model the agency problem between entrepreneurs and the bank. Note that while the MH model is written more general, it nests this interpretation of investors as depositors and bond holders of a bank. This interpretion is appropriate in the context
} 
This paper uses a unique matched firm-bank credit contract dataset and to assess which of these two models most accurately represents the data and thus which of the two channels is the most relevant in the small business lending market. I first conduct a structural analysis to assess the empirical plausibility of each channel through the lens of the models. Next, I derive additional testable implications from the models and take them to the data. The results of this study therefore shed light on the mechanism generating the actual financing constraint in the small business lending market. I extend the models to distuishing working capital and pure collateral. The different ways of modeling financial frictions and the implied importance of each channel can have significant consequences for the success of policies aimed at improving small businesses credit availability. The SBLF, for example, provides additional capital to qualified community banks with assets of less than $\$ 10$ billion to increase lending to small businesses. This policy will serve to improve credit conditions if the financial frictions that exist in supplying credit to small businesses work as characterized by the bank balance sheet channel - that is, scarce bank capital constrains lending. However, the policy will do little to improve small business credit availability if a worsening of entrepreneurial balance sheets constrains small business lending. ${ }^{5}$

Even though it is crucial to know which channel is the most relevant for small business lending, with few exceptions the literature on financial frictions in credit intermediation has given only limited attention to distinguishing empirically which strategy for modeling such frictions is a better representation of reality. Moreover, little of this analysis has focused on small business lending. ${ }^{6}$ Much of the early literature, for example, focused only on whether financing constraints were indeed relevant for investment decisions of large firms, but gave little emphasis to the mechanism generating the actual financing constraint. Moreover, most of the literature did not use debt contract data in the analysis. ${ }^{7}$ Subsequent research did focus on evaluating various strategies for modeling financial frictions, but did so by focusing on only one modeling strategy without actually comparing different ones. $^{8}$

of small business credit market as small businesses do not issue bonds.

${ }^{5}$ The subsidy in the SBLF capital provision schedule may also increase lending in the CSV model by lowering the return that the marginal project needs to earn. However, the effects are expected to be much smaller than in $\mathrm{MH}$ model, which implies a large loan increase from additional bank capital.

${ }^{6}$ Many macroeconomic models include financial friction. Yet little attention has been paid to the microfoundations of the modeling strategy these models employ. Following Carlstrom and Fuerst (1997) and Bernanke, Gertler, and Gilchrist (1999) the CSV model is the standard approach for modeling financial frictions (see, for example, Christiano, Motto, and Rostagno (2007), Christensen and Dib (2008), von Heideken (2009), Gilchrist, Ortiz, and Zakrajšek (2009), and Nolan and Thoenissen (2009)). Chen (2001) and Meh and Moran (2010) include the MH model in dynamic general equilibrium models. A growing literature in development economics tries to disentangle different models of financing constraints and insurance for households. However, these tests are generally carried out without using credit contract data. See, for instance, Paulson, Townsend, and Karaivanov (2006).

${ }^{7}$ See Fazzari, Hubbard, and Petersen (1988), and the subsequent literature criticizing this approach: Kaplan and Zingales (2000), Gomes (2001), Alti (2003), and Cummins, Hassett, and Oliner (2006). Offering an alternative approach, Chava and Roberts (2008) find that debt covenants violations by large firms reduces investment.

${ }^{8}$ See Levin, Natalucci, and Zakrajšek (2004), Hennessy and Whited (2007), and Sufi (2007). 
Arguably one constraint on the profession's ability to assess different models of financing frictions has been the dearth of data sources with information about borrowers and lenders in a credit contract. The FRB's Survey of Small Business Finances (SSBF) provides such a source on small businesses that are bank dependent with no access to bond markets. I use the SSBF, including confidential information on the bank extending each loan, to construct a unique matched firm-bank credit contract data set. The SSBF contains detailed information about small businesses and their loans. Small businesses here are defined as firms with fewer than 500 employees. I use the 1998 and 2003 surveys, which each consist of a representative sample of the roughly 6 million small businesses in the U.S.

Using this dataset I study which channel of financing frictions most accurately captures the constraints that exist in the small businesses lending market. The approach and the layout of the paper are as follows. To assess each strategy for modeling financial frictions, I first conduct a structural analysis, using the relevant business owner and bank balance sheet information. Second, I also derive and test additional implications. In section 2 I solve for the bankruptcy costs, rates of return, and riskiness implied by the optimal debt contract with the CSV model. In section 3 I calculate the interest rate implied by the specific version of the $\mathrm{MH}$ model that is used in the literature. I also solve for the implied agency cost in this model, commonly interpreted as monitoring cost, for which the model implied interest rate calculation uses non-interest expense as a proxy.

In brief, the results of this analysis are as follows. First, CSV debt contracts can rationalize more than two-thirds of the credit contracts with plausible parameter values. In line with earlier studies on bankruptcy costs and on rates of return on entrepreneurial investment, the implied bankruptcy costs are 28 percent of expected output, and the implied rate of return lies between 5 percent and 8 percent annually. Second, for the MH model, I find that the correlation between model-implied interest rates and actual interest rates is close to zero. Median implied agency cost ranges from 2 to 5 percent of the loan amount. However more than 60 percent of the observations yield implausible agency cost. Therefore, through the lens of these models, the firm balance sheet channel appears to be the most relevant financial friction in the small business lending market.

To ensure that the results are not driven by the specific formulation of the agency problem, I complement the structural analysis with reduced-form regressions and find, that in almost all instances, bank balance sheet variables cannot explain loan interest rates. Next, I consider loan amounts. Consistent with both models of financing frictions an additional dollar of net worth accounts for about 30 cents of additional external finance in the small business credit market. Again contrary with the implications of agency problems between a bank and the bank's depositors and bond holders, bank balance sheet variables have no significant effect on the loan amounts. 
What do the results of this paper mean for the effectiveness of policy measures? Most measures such as the SBLF have focused on banks. Yet the analysis in this paper suggests that bank variables have little impact on loan contracts. ${ }^{9}$ Similarly, there is no evidence that bank variables except for bank size are important in the bank's decision to approve a loan application. Net worth and the overall quality of firms, however, exhibit a high explanatory power for loan amounts, loan interest rates, and the bank's approval decision. Since entrepreneurs use personal guarantees and their private residences as collateral for loans, the sharp decline in house price has reduced collateral values, resulting in a worsening of small business balance sheet conditions (and lower credit scores), which in turn reduced credit availability to small businesses. Therefore, the SBLF, even though directed to the banks most likely to lend to small businesses, may provide only limited stimulus to small business lending. The evidence presented here suggests that the best way to help small businesses obtain credit is to stabilize the housing market and support entrepreneurs in repairing their balance sheets with loan modification programs.

The paper proceeds as follows: Section 2 describes the debt contract with costly state verification and estimates the agency cost implied by this model. Section 3 introduces the bank-depositor and bank bond holder agency model of financing constraints and assesses the empirical plausibility of this agency problem. Section 4 tests additional implications of both agency problems. Differences by bank size are discussed in section 5 . Section 6 concludes the paper.

\section{Borrower-Lender Agency Problems}

This section first describes the debt contract with CSV, which models agency problems between borrowers and lenders. I extend the model to distuishing working capital and pure collateral such as real estate. It then summarizes the data used to assess the empirical plausibility of this modeling strategy of financing constraints. Last, it presents the parameter distribution for the agency cost - that is, the bankruptcy cost — and the rate of return implied by the debt contract with CSV for each observation in the data.

\subsection{The Debt Contract with CSV}

The CSV model recognizes asymmetric information between the lender and the borrower. The lender can not observe the outcome of a leveraged project. If a bankruptcy occurs the lender incurs a cost to verify the outcome. This CSV ties the ability to obtain credit to the net worth of

\footnotetext{
${ }^{9}$ The data employed here are from time periods in which did not suffer liquidity problems. Calem, Covas, and Wu (2011) find that in the 2007 collapse of the RMBS market, bank capital had an effect on lending as higher capitalized banks were able to smoothen this liquidity shock. However, the SBLF focuses on banks that do not rely on such instruments to fund themselves.
} 
an entrepreneur (Townsend, 1979). Gale and Hellwig (1985) show that in a world with CSV the optimal, incentive-compatible financial contract is the standard debt contract. The debt contract with CSV is now widely used in macroeconomic models and models of firm growth. ${ }^{10}$

To derive the optimal one-period debt contract, I first describe the preferences and technology of both borrowers and lenders. Risk neutral entrepreneurs own a risky return technology; entrepreneurs can finance their capital stock with equity and debt. If an entrepreneur borrows, she signs the standard one-period debt contract, which in the presence of CSV is the optimal contract. To better understand the implications of the underlying financing constraint, I abstract from aggregate uncertainty differences in productivity and equity issuance. ${ }^{11}$

Let $k_{i}$ be the capital stock used in production by entrepreneur $i$. The vast majority of credit applications in the data, which I describe in the next section, show that credit is used for working capital. Hence, I consider the case of full depreciation. The entrepreneur can only use a fraction $\xi$ of her net worth $n$ in production but can borrow $d_{i}=k_{i}-\xi_{i} n_{i}$ to produce at scale $k_{i}$. She signs a one-period debt contract with a financial intermediary, the lender, specifying the credit amount and the gross interest rate $Z_{i}$. The fraction $\left(1-\xi_{i}\right)$ of net worth is pure collateral such as land or buildings. In line with financing constraints employed in macroeconomic models, I assume a constant return to scale technology. The payoff of production with external financing is:

$$
\Pi_{i}=\omega_{i} R_{i}^{k} k_{i}+\left(1-\xi_{i}\right) n_{i}-Z_{i} d_{i}
$$

where in the first term $\omega_{i}$ is an idiosyncratic productivity shock and $R_{i}^{k}$ is the rate of return. The productivity shock $\omega$ is unknown at the time when the debt contract is signed and i.d.d. across time. The random variable has a continuous differentiable c.d.f., $F(\omega)$ and $E(\omega)=1$. The distribution satisfies the following regularity condition: $\frac{\partial h(\omega)}{\partial \omega}>0$, where $h(\omega)$ is the hazard rate. This assumption guarantees that an interior solution is a non-rationing outcome. The property holds for, among others, the lognormal distribution. The second term, $\left(1-\xi_{i}\right) n_{i}$, is the pure collateral component of net worth.

Financial intermediaries, offering loans to entrepreneurs, are risk neutral, perfectly competitive, and hold perfectly diversified portfolios. The opportunity cost of funds for financial intermediaries is the economy's riskless gross rate of return $1+r$. Financial intermediaries do not observe the realization of the idiosyncratic productivity shock. Lenders have to pay a cost to be able to observe the borrower's productivity shock. As in Carlstrom and Fuerst (1997) monitoring costs in the case of bankruptcy are assumed to be a fraction $\mu_{i}$ of the expected output.

\footnotetext{
${ }^{10}$ See, for example, Carlstrom and Fuerst (1997), Bernanke, Gertler, and Gilchrist (1999), and Cooley and Quadrini (2001).

${ }^{11}$ For models with debt/equity choice using the CSV, see Cooley and Quadrini (2001), Hennessy and Whited (2007), and Covas and den Haan (2011).
} 
The entrepreneur defaults on the debt if, after the realization of the idiosyncratic shock, she does not have enough resources on hand to pay back the loan. Let $\bar{\omega}_{i}$ be the cutoff productivity for which the entrepreneur can just repay her debts:

$$
\bar{\omega}_{i} R_{i}^{k} k_{i}+\left(1-\xi_{i}\right) n_{i}=Z_{i} d_{i}
$$

In case of default, the financial intermediary pays the cost $\mu_{i} R_{i}^{k} k_{i}$ and seizes the firm's remaining assets. The default payoff to the lender is

$$
\omega_{i} R_{i}^{k} k_{i}+\left(1-\xi_{i}\right) n_{i}-\mu_{i} R_{i}^{k} k_{i}
$$

Financial intermediaries are assumed to be perfectly competitive. Their zero profit condition has to hold in expectation on each contract. Using equation 2, the zero profit condition of the lender can be written as

$$
\int_{\omega_{i}}^{\infty}\left(\bar{\omega}_{i} R_{i}^{k} k_{i}\right) d F(\omega)+\int_{0}^{\bar{\omega}_{i}}\left(\omega_{i} R_{i}^{k} k_{i}-\mu_{i} R_{i}^{k} k_{i}\right) d F(\omega)+\left(1-\xi_{i}\right) n_{i}=(1+r)\left(k_{i}-\xi_{i} n_{i}\right),
$$

and the entrepreneur's expected income is

$$
\int_{\bar{\omega}_{i}}^{\infty} \omega_{i} R_{i}^{k} k_{i} d F(\omega)-\left(1-F\left(\bar{\omega}_{i}\right)\right) \bar{\omega}_{i} k_{i}
$$

The loan contracts, in general, specify a pair of $\left(k_{i}-\xi_{i} n_{i}, Z_{i}\right)$. Here it is convenient to use the definition of the cutoff productivity $\bar{\omega}_{i}$ and to rewrite the problem as a choice over $\left(k_{i}, \bar{\omega}_{i}\right)$. The solution to the optimal contract maximizes over these two variables the expected payoff to the borrower subject to the zero profit condition on the lender.

$$
\max _{k_{i}, \bar{\omega}_{i}} \Gamma\left(\bar{\omega}_{i}\right) R_{i}^{k} k_{i}
$$

subject to

$$
G\left(\bar{\omega}_{i}\right) R_{i}^{k} k_{i}+\left(1-\xi_{i}\right) n_{i}=(1+r)\left(k_{i}-\xi_{i} n_{i}\right)
$$

where $\Gamma\left(\bar{\omega}_{i}\right)=\int_{\bar{\omega}_{i}}^{\infty} \omega_{i} d F(\omega)-\left(1-F\left(\bar{\omega}_{i}\right)\right) \bar{\omega}_{i}$ is the firm's share of output and $G\left(\bar{\omega}_{i}\right)=\left(1-F\left(\bar{\omega}_{i}\right)\right) \bar{\omega}_{i}+$ $\int_{0}^{\bar{\omega}_{i}} \omega d F(\omega)-\mu_{i} F\left(\bar{\omega}_{i}\right)$ is the the lender's share of output. The combined shares of the lender and the borrower are together less than 1: $\Gamma\left(\bar{\omega}_{i}\right)+G\left(\bar{\omega}_{i}\right)=1-\mu_{i} F\left(\bar{\omega}_{i}\right)$. The last term illustrates the distortion caused by asymmetric information about the idiosyncratic shock. An increase in the cutoff productivity $\bar{\omega}_{i}$, equivalent with more bankruptcies, or an increase in the monitoring cost lead to larger distortions. Let $\lambda$ be the multiplier on the lender's zero profit constraint. The 
problem can be scaled by $n_{i}$ and solved for the optimal leverage, the capital-to-net worth ratio

$$
L_{i}=k_{i} / n_{i}
$$

for all entrepreneurs. ${ }^{12}$ The external finance premium is defined as the rate of return over the risk free rate: $R_{i}^{k} /(1+r)$. Combing the first order condition for $\bar{\omega}_{i}$ and $k_{i}$ gives

$$
\frac{R_{i}^{k}}{(1+r)}=\frac{1}{G\left(\bar{\omega}_{i}\right)-\Gamma\left(\bar{\omega}_{i}\right) \frac{G^{\prime}\left(\bar{\omega}_{i}\right)}{\Gamma^{\prime}\left(\bar{\omega}_{i}\right)}} .
$$

Note that $\Gamma^{\prime}\left(\bar{\omega}_{i}\right)=-\left(1-F\left(\bar{\omega}_{i}\right)\right)$ and $G^{\prime}\left(\bar{\omega}_{i}\right)=-\Gamma^{\prime}\left(\bar{\omega}_{i}\right)-\mu_{i} F^{\prime}\left(\bar{\omega}_{i}\right)$. In an interior optimum $G^{\prime}\left(\bar{\omega}_{i}\right)>0$ otherwise the bank could increase profits by lowering $\bar{\omega}_{i}{ }^{13}$ By inverting the function, Bernanke, Gertler, and Gilchrist (1999) show that $\bar{\omega}_{i}$ is increasing in $\frac{R_{i}^{k}}{(1+r)}$. Rewriting the zero profit condition of the lender yields:

$$
L_{i}=\frac{1+r \xi_{i}}{(1+r)\left(1-G\left(\bar{\omega}_{i}\right) \frac{R_{i}^{k}}{(1+r)}\right)} .
$$

The zero profit condition of the lender implies that the amount of credit covered by collateral, $\left(1-\xi_{i}\right) n_{i}$, needs to earn the risk free rate. This introduces an additional wedge in the choice of leverage. ${ }^{14}$

The optimal contract trades off the return on an additional unit external finance against a rise in bankruptcy states, that is, higher agency costs. The equilibrium contract, defined as a pair of $\left(L_{i}, \bar{\omega}_{i}\right)$, depends on four parameters: 1$)$ the external finance premium $\left.\frac{R_{i}^{k}}{(1+r)}, 2\right)$ the variance of the idiosyncratic shock $\sigma_{i}$, which measures risk, 3) the bankruptcy cost $\mu_{i}$, and 4) the fraction of net worth used in production $\xi_{i}$.

\footnotetext{
${ }^{12}$ In other words, if entrepreneurs' projects are identical, net worth matters for the total amount of credit, but in equilibrium all entrepreneurs have the same leverage and the same cutoff productivity $\bar{\omega}$. This feature simplifies having financing constraints in general equilibrium models.

${ }^{13}$ The value of the Lagrange multiplier on the bank's zero profit condition depends only on the cutoff productivity

$$
\lambda=-\frac{\Gamma^{\prime}\left(\bar{\omega}_{i}\right)}{G^{\prime}\left(\bar{\omega}_{i}\right)} \geq 1 .
$$

Intuitively, without the presence of bankruptcy cost, $\mu=0$, the credit would not be risky and the Modigliani-Miller theorem holds. The marginal unit of capital can be financed with either net worth or credit without changing the payoff of the lender and $\lambda=1$. If the entrepreneur has to take out a risky loan, then the multiplier reflects the shadow value of agency costs that are increasing in $\bar{\omega}_{i}$.

${ }^{14}$ Any additional cost of repossessing collateral reduces leverage further. To see this reduction, assume that in case of bankruptcy the bank only receives $\left(1-\mu_{i}\right)\left(1-\xi_{i}\right) n_{i}$. The optimal leverage now is $L_{i}=\frac{1+r \xi_{i}-\mu_{i} F\left(\bar{\omega}_{i}\right)\left(1-\xi_{i}\right)}{(1+r)\left(1-G\left(\bar{\omega}_{i}\right) \frac{R_{i}^{k}}{(1+r)}\right)}$, which is lower than without additional repossession cost. Hennessy and Whited (2007) estimate the cost of repossessing to be 10 percent of the capital stock. However, their point estimate is not significant. One interpretation of this repossession cost is the homestead exemption in bankruptcy laws. Berkowitz and White (2004) find that higher exemptions reduce access to credit significantly.
} 


\subsection{Credit Contracts and Net Worth Data}

This section describes the data used to assess the empirical plausibility of the debt contract with CSV. In particular, it summarizes the construction of the crucial variables: the net worth $n_{i}$, the probability of bankruptcy $F\left(\bar{\omega}_{i}\right)$, the credit amount $d_{i}$, the share of collateral $\xi_{i}$ and the interest rate $Z_{i}$.

The SSBFs (previous to 1998 known as the National Survey for Small Business Finances) was conducted by the Federal Reserve Board for the fiscal years ending in 1987, 1993, 1998, and 2003. The surveys aim to assess credit availability, provide financial statement data of small firms, and study the effects of changes through technology and mergers in the banking sector. Within the surveys, small businesses are defined as firms with fewer than 500 employees. The representative samples were drawn from the Dun and Bradstreet database. ${ }^{15}$ In addition to the standard firm characteristics such as number of employees, sales, region, and industry, the SSBFs also provide additional information on the most recent credit (amount, interest rate) and measures of riskiness of a credit: the Dun and Bradstreet credit score and indicators of whether the firm had declared bankruptcy or had delinquent obligations or judgments. For the business owner, the same indicators are available except for the personal credit score.

Personal net worth, separated by net home value and other assets, is the crucial variable used to construct net worth of a merged firm-household entity and is only available for the 1998 and 2003 surveys. ${ }^{16}$ Therefore, I restrict my analysis to the last two cross sections. The SSBFs provide a final, representative sample of 3,561 firms in 1998 and 4,240 firms in 2003. The sample weights imply that the 1998 sample represents 5,291,245 firms and the 2003 sample represents 6,298,087 firms. Table 1 summarizes the the standard firm characteristics for the SSBF data employed here. ${ }^{17}$

To evaluate the agency cost implied by the debt contract with CSV, I use the SSBF data to

\footnotetext{
${ }^{15}$ A detailed description of the sampling procedure can be found in the methodology reports. Firms were asked to use tax data and previously sent worksheets to answer the questions. The public data and methodology reports to all surveys can be downloaded at http://www.federalreserve.gov/Pubs/Oss/Oss3/nssbftoc.htm.

${ }^{16}$ For a description of earlier surveys, see Berger and Udell (1998).

${ }^{17}$ The composition of small businesses in the 1998 and 2003 surveys are comparable. The average number of employees was 8.6 and the median number of employees was 3 in both samples. Firms in the manufacturing sector (SIC 20-39) have on average more than twice as many employees as the firms in the service sector (SIC 70-89) and insurance and real estate (SIC 64-65) sectors. Average firm age increases from 13.3 years in the SSBF 1998 to 14.3 years in the SSBF 2003 after falling from 14.5 years in the SSBF 1993. The median also increased by 1 year from 11 years to 12 years. The vast majority of the firms have only a few employees and are owner-managed (94 percent), and less than 30 percent of the firms reported annual sales of more than $\$ 500,000$. Thirty-five percent of small businesses were located in the South, 24 percent in the West, 21 percent in the Midwest, and 20 percent in the Northeast. Roughly 4 out of 5 firms had their headquarters or main office in urban areas, and 44.5 percent (1998: 49.4 percent) of firms were proprietorships, 8.7 percent ( 7 percent) partnerships, 31 percent (23.9 percent) C-Corporations, and 15.8 percent (19.8 percent) S-Corporations. For more detailed descriptive statistics, see appendix. Bitler, Robb, and Wolken (2001) and Mach and Wolken (2006) provide descriptive statistics, summarizing the financial services used by small businesses for the SSBF 1998 and 2003, respectively.
} 
construct net worth of the firm-household entity $\left(n_{i}\right)$ as follows. The literature defines net worth as maximum (collateralizable) assets, which is the sum of liquid and collateralizable illiquid assets less all obligations. ${ }^{18}$ For small businesses, the owner may collateralize credit with private net worth. To construct a measure of net worth of the firm-household entity that is consistent with a bank's definition of net worth, I examine the application process performs welland the collateral accepted by banks in detail.

Giambona and Schwienbacher (2008) argue that only "hard" tangible assets, namely land and buildings, can be collateralized. Yet almost 45 percent of borrowers used equipment as collateral, 23 percent used their business real estate, and 24 percent used their private residence. Accounts receivable and inventory was accepted as collateral in 23 percent of the cases. ${ }^{19}$ The main difference between the two surveys is the shift from equipment (1998: 55 percent, 2003: 39 percent) to the private residence (1998: 15 percent, 2003: 29 percent) as the source of collateral. The increase in the house prices between the two samples may explain this shift. While in the 1998 sample, the average net value of the private residence is $\$ 128,915$ (median: $\$ 75,000$ ), the average net value increases to $\$ 232,632$ (median: $\$ 120,000$ ) in the 2003 sample. Only about 6 percent of borrowers use "other" personal assets beyond the private residence to collateralize their credit.

Alternatively, owners may provide a personal guarantee - that is, the owner declares an individual pledge to repay the business loan. Depending on the credit contract, the owner may be held responsible for the business loan even if the business is protected by limited liability laws or gets dissolved. In the pooled 1998 and 2003 SSBF, 52 percent of the firms reported that collateral was required to receive credit, 54 percent gave personal guarantees, and 30 percent provided both. This is in line with Sullivan, Warren, and Westbrook (1989) who, using bankruptcy data, show that entrepreneurs are more likely to file personal bankruptcy as firm credits are collateralized or guaranteed by the owner's private net worth.

The patterns of collateral strongly suggest a wider definition of net worth than the one advocated by Giambona and Schwienbacher (2008). I construct net worth from the data as follows: Using balance sheet information, I subtract all liabilities from total assets to calculate firm equity. Following the patterns of collateral, I add the net value of the private residence for firm owners who own a house. Table 2 displays the equity share of total assets - total equity divided by total assets (firm+residence), $\frac{\text { net worth }}{\text { capital }}$, which is the inverse of leverage. ${ }^{20}$ The equity share of assets of a

\footnotetext{
${ }^{18}$ See, for example, Bernanke and Gertler (1989).

${ }^{19}$ In the credit application process, banks require a business financial statement and a personal financial statement. The business financial statement includes balance sheet information, information on accounts receivable, organizational form, and other business characteristics. The personal financial statement asks for a detailed description of assets and liabilities, including the net value of the private residence, total net worth, and previous bankruptcies. For detailed application forms, see Cavalluzzo and Wolken (2005). About 25 percent of the firms provided more than one type of collateral.

${ }^{20}$ Some of the firm-household entities have no positive equity. Their equity share is zero.
} 
firm-household entity with negative equity is 0 . Table 2 provides the summary statistics for the full sample and for firms that received credit. Not all firms applied for and received credit. Younger firms have less net worth and a lower equity share of assets than older firms. Similarly, firms that received credit have more net worth than the average firm in the total sample in each age group. However, the equity shares of firms that received credit are indistinguishable from the total sample. On average, the equity shares translate into a leverage (the capital-to-net worth ratio) of 1.5 or an equity-to-debt ratio of 2 , and lie in the range of 1.3 to 2 for the leverage ratio documented by Masulis (1988).

It is worth noting that in the $2003 \mathrm{SSBF}$ more than 63 percent of the entrepreneurs used credit for working capital, while about 20 percent indicated investment activity (9.9 percent vehicles loans and 10.2 percent equipment loans) and another 9.4 percent took out mortages. In the 1998 SSBF, the share of credit used for investment activity was roughly 35 percent. The difference in investment activity occurs because renewals of credit lines were not included in the 1998 questionaire. Only 6 to 8 percent of the samples raised new equity. The usage of new equity in both surveys exhibits the same pattern. Since most of the credit is used for working capital, I assumed complete depreciation in the previous section.

To fit the debt contract with CSV described in the previous section to the data, I use the net worth of the firm-household entity for $n_{i}$. Information on the most recent loan application and the riskiness of the loan are used to proxy for additional parameters of the model. In particluar, the SSBFs information on the firm's most recent loan application includes the bank's name, whether the credit application was approved and, if so, the details of the credit contract; in particular, the loan amount $\left(d_{i}\right)$ and the interest rate $\left(Z_{i}\right)$. The share of collateral $\left(\xi_{i}\right)$ is proxied by the share of fixed assets (land, buildings, and machinery). The Dun and Bradstreet credit score, included in the SSBF, measures the probability of bankruptcy $\left(F\left(\bar{\omega}_{i}\right)\right)$.

\section{$2.3 \quad$ Fitting the CSV Debt Contract}

To assess the empirical plausibility of borrower-lender agency problems as modeling strategy for financing constraints in the context of this model, two questions need to be answered: 1) whether parameters for the model can be derived from the actual debt contracts - that is, whether a system of equations constituting the CSV contract can be solved for each observation and if so, 2) whether the implied parameter values for the bankruptcy cost and the rate of return are plausible when compared to studies of bankruptcies and returns to entrepreneurial capital investments. To answer these questions, I use the observed credit contract characteristics - credit amount, interest rate, net worth, and credit score - to solve for the implied parameters of a CSV debt contract. The share of fixed assets, such as land and buildings, of total firm assets in the SSBFs is 0.33. Hence, 
the fraction of the net worth used in production $\xi$ is on average 0.67 .

The methodology follows Levin, Natalucci, and Zakrajšek (2004). While Levin, Natalucci, and Zakrajšsek (2004) use bond data to construct empirical equivalents to one-period debt contracts and analyze CSV, this study uses bank credit contracts to back out the implied parameters - the agency cost $\mu_{i}$, the standard deviation of the underlying log-normal distribution $\sigma_{i}$, the rate of return $R_{i}^{k}$, and the cutoff productivity $\bar{\omega}_{i}$ - of the CSV credit contract for each observation $i$ in the SSBF. The following four equations need to be solved by the parameters: (1) the definition of the cutoff productivity, equation 2 ,

$$
\bar{\omega}_{i} R_{i}^{k} L_{i}+\left(1-\xi_{i}\right)=Z_{i}\left(L_{i}-\xi_{i}\right)
$$

(2) the optimality conditions, equations 8 and 19 ,

$$
\frac{R_{i}^{k}}{(1+r)}=\frac{1}{G\left(\bar{\omega}_{i}\right)-\Gamma\left(\bar{\omega}_{i}\right) \frac{G^{\prime}\left(\bar{\omega}_{i}\right)}{\Gamma^{\prime}\left(\bar{\omega}_{i}\right)}}
$$

and

$$
L_{i}=\frac{1+r \xi_{i}}{(1+r)\left(1-G\left(\bar{\omega}_{i}\right) \frac{R_{i}^{k}}{(1+r)}\right)},
$$

and (3) the probability of bankruptcy

$$
F\left(\bar{\omega}_{i}\right)=\text { taken from credit score. }
$$

The distribution of the idiosyncratic shock $F(\omega)$ is log-normal with $E(\omega)=1$. In the data, firms differ in their rate of return $R_{i}^{k}$, risk $\sigma_{i}$, and bankruptcy cost $\mu_{i}$. For instance, an increase in the rate of return increases the returns to external finance, which implies that a higher leverage is therefore optimal. The higher leverage then implies a higher cutoff productivity and thereby a higher interest rate paid on the loan $Z$. An increase in variance of the idiosyncratic shock, however, makes low productivity states more likely to occur as $E(\omega)=1$. With a higher variance optimal contract exhibits a lower leverage and a higher interest rate (see figure 1). Incomplete depreciation does not change these results but scales up leverage and reduces the probability of bankruptcy.

In constructing leverage $L_{i}$, I use the credit amount on the most recent credit and net worth. The interest rate on the credit in the data is used to calibrate $Z_{i}$ in equation 2 . The risk-free rate $r$ is set to the federal funds rate at the time the credit was contracted. The annual risk-free rate is about 5 percent for the $1998 \mathrm{SSBF}$ and 1 percent for the 2003 observations, depending on the respective quarter the loan was taken out. The bankruptcy rate is taken from the Dun and Bradstreet credit scores. The credit scores provided in the SSBF indicate the probability of 
delinquency (payments are at least 90 days late) rather than bankruptcy. ${ }^{21}$ Therefore, I assume that firms that are more likely to miss payments are also more likely to file for bankruptcy. I scale the probability of delinquency incidents to match a quarterly bankruptcy rate of 1 percent as reported in Fisher (1999). Constructing the bankruptcy rate this way yields firms with the highest score (6) having a quarterly failure probability of 0.19 percent, while 4.44 percent of firms with the lowest credit score (1) are expected to fail in the 2003 sample. In 1998, the probability of failure for the best (worst) risks is 0.15 percent (3.52 percent).

In some cases, there is no solution to the system of equations describing the credit contract - for instance, when the firm-entrepreneur entity has no net worth. In 1998, 599 out of 660 observations can be rationalized by one-period debt contracts with CSV. In 2003, 1,413 out of 1,598 observations can be rationalized. Sometimes the solution involves implausible values such as negative agency cost. In the 1998 sample, 114 observations exhibit a fitted agency cost less than 0 or greater than 1 . In the 2003 sample, 364 observations cross these thresholds. However, for 73 percent of the observations in 1998 (485 out of 660) and 67 percent of the observations in 2003 $(1,079$ out of 1,598$)$, the system of equations can be solved with plausible parameter values.

Table 3 summarizes the results. In 1998, the average agency cost $\mu$ is estimated to be 0.282 (stddev 0.09), which corresponds to 28.2 percent of expected output. In 2003, the agency costs are 0.287 (stddev 0.10). This lies in the plausible range of 0.2-0.36 reported in Carlstrom and Fuerst (1997). ${ }^{22}$ Figure 2 plots the implied risk parameters and bankruptcy cost for the truncated sample. As reflected in table 3, the bankruptcy costs are clustered within the $0.2-0.36$ range. ${ }^{23}$ The mean standard deviation of the idiosyncratic shock, $\sigma$, measuring the riskiness of projects is 0.57 (stddev 0.25) in 1998. In 2003, the average standard deviation is 0.57 (stddev 0.24). In comparison, the calibration strategy of Carlstrom and Fuerst (1997) yields $\sigma=0.21$ and the one of Bernanke, Gertler, and Gilchrist (1999) yields $\sigma=0.53$.

The implied annualized rate of return is 8 percent in 1998 and 5 percent in 2003 . These averages are close to the estimates of Moskowitz and Vissing-Jørgensen (2002), who, using flow of funds accounts and the national income and product accounts data from 1963 to 1999, find that the average annual rate of return to entrepreneurial investment is 13 percent with a standard deviation of 7.7. Their calculation is based on equity in the firm only. Taking into account that the definition of net worth in my analysis includes the net value of the private residence, the annual return on

\footnotetext{
${ }^{21}$ For a detailed discussion, see http://www.dnb.com.

${ }^{22}$ When setting the share of net worth used in production $\xi_{i}$ to 1 for all observations, 70 percent of the 1998 sample and 77 percent of the 2003 sample can be fitted with plausible parameter values. However, the average agency cost and average standard deviations of the idiosyncratic shock are close to the ones reported in table 3.

${ }^{23}$ Bernanke, Gertler, and Gilchrist (1999) formulate the agency cost in terms of realized output and argue for lower values (0.12). Lower values for the bankruptcy cost are consistent with higher bankruptcy rates in their calibration (2.72 percent per quarter).
} 
equity in the firm would be about 12 percent in 1998 and 7.5 percent in 2003.

The parameter distributions in table 3 contain some implausible extreme values, such as negative or high bankruptcy cost. A closer investigation of these observations through the lens of the model helps to understand the extreme values. Observations with implied negative bankruptcy cost exhibit a high leverage, on average 8.7, while paying only 34 basis points more. The implied risk parameter for this subgroup is only 0.08 while the rate of return is 1 . In other words, the model is unable to explain high leverage and low risk premiums for the given bankruptcy rates. Figure 1 illustrates that eithpotentialer low risk or high rates of return lead to higher leverage in the model. Yet in the model, high rates of return also lead to significantly higher interest rates. Since the interest rates in the data are not significantly higher, risk must be low. With the mean of the idiosyncratic shock normalized to 1 , the lender must receive an additional reward in the case of bankruptcy to rationalize the high leverage.

Observations with high bankruptcy cost $\left(\mu_{i}>1\right)$ exhibit a low leverage, but the firms in the subgroup pay on average a premium of 72 basis points over the full sample despite a lower-thanaverage bankruptcy rate. In the context of the model, given the lower bankruptcy rate, the cost of lending must be higher for this subgroup. The spread can be increased by a higher fraction of output lost in the case of bankruptcy or a higher rate of return, which in itself increases the cost of bankruptcy as bankruptcy costs are measured in terms of expected output (the fraction $\mu_{i}$ ). In fact, for this subgroup the model also implies an average rate of return of 1.15 with lower than average risk.

Solving for the implied parameter of the optimal debt contract relies on three assumptions: 1) the idiosyncratic shock has a lognormal distribution, 2) the credit score is a good proxy for the bankruptcy rate, and 3) net worth is measured correctly. Measurement error in net worth or the bankruptcy rate may explain the extreme values of the model-implied parameter distributions. Also, the assumption of a lognormal distributed idiosyncratic shock may also be too restrictive, yet it is commonly used.

Despite these pitfalls, modeling financing constraints an agency problem between borrowers and lenders with competitive lending performs well vis-à-vis the data. The specific modeling strategy can rationalize more than two-thirds of the credit contracts with plausible parameter values. The implied rate of returns are in line with results using flow of funds accounts and the national income and product accounts data and bankruptcy costs are consistent with studies on bankruptcy incidences. 


\section{Lender-Investor Agency Problems}

In this section, I first describe a model of agency problems between lenders and investors, in particular the debt contract with moral hazard in monitoring as introducted by Holmström and Tirole (1997). In the context of small business lending the bank's depositors and bond holders should be interpreted as the investors, though the $\mathrm{MH}$ model is more general. Again, I extend the model to distuishing working capital and pure collateral. Next, I present the additional bank level data used in this section. I plot the model implied interest rate and the interest rate observed in the data using a standard proxy for agency costs. Next, dropping the proxy, I back out the implied agency cost. Last, I complement my findings with the monitoring cost implied by the debt contract with $\mathrm{MH}$ and reduced-form regressions.

\subsection{The Debt Contract with Moral Hazard by Holmström-Tirole}

In the MH model by Holmström and Tirole (1997), risk-neutral entrepreneur $i$ owns a risky return technology. She can invest in either a high-quality project with a high probability of success $\alpha_{i}^{g}$

or a low-quality project with a lower probability of success $\alpha_{i}^{b}$ but with private benefit to the entrepreneur $b_{i} k$, where $k_{i}$ denotes working capital in production. In case of success $k_{i}$ is converted into output with constant returns to scale. If the project fails, the capital is lost. The entrepreneur's project choice is not observable. Bank $j$ has to pay the fraction of the loan as monitoring cost $\mu_{j}$ to ensure that the entrepreneur invests in the high-quality project. The lender's capital $a_{j}$ is scarce. The lender's equity share in the loan to an entrepreneur has to earn a rate of return $r_{j}^{b}$ reflecting outside investment opportunities. Investors in this model can be thought of as bank bond holders and depositors who can only invest into a project through the bank. Deposits $h_{j}$ at lender $j$ have to earn a return $r_{j}^{h}$. The crucial assumption of the model is $r_{j}^{b}>r_{j}^{h}$.

As in CSV collateral is the share of net worth $\left(1-\xi_{i}\right) n_{i}$ that cannot be used in production. I assume that in case of default, all collateral is going to the lender. The results are not sensitive to this assumption, as, in equilibrium, only the combined shares of output going to the lender and the depositors matter. Let $R_{i}$ be the total rate of return to the project, $R_{i}^{e}$ the entrepreneur's share of the total rate of return, $R_{i}^{b}$ the bank's share, and $R_{i}^{h}$ the depositors' share. The optimal contract maximizes the payoff to the entrepreneur:

$$
\max _{k_{i}, a_{j}, h_{j}, R_{i}^{e}, R_{i}^{h}, R_{i}^{b}} \alpha_{i}^{g} R_{i}^{e} k_{i}
$$

subject to the incentive compatibility constraint of the entrepreneur

$$
\alpha_{i}^{g}\left(R_{i}^{e} k_{i}+\left(1-\xi_{i}\right) n_{i}\right) \geq \alpha_{i}^{b}\left(R_{i}^{e} k_{i}+\left(1-\xi_{i}\right) n_{i}\right)+b_{i} k_{i}
$$


the incentive compatibility constraint of the lender (monitoring)

$$
\alpha_{i}^{g} R_{i}^{b} k_{i}+\left(1-\alpha_{i}^{g}\right)\left(1-\xi_{i}\right) n_{i}-\mu_{j}\left(k_{i}-\xi_{i} n_{i}\right) \geq \alpha_{i}^{b} R_{i}^{b} k_{i}+\rho\left(1-\alpha_{j}^{b}\right)\left(1-\xi_{j}\right) n_{j},
$$

the participation constraint of the lender

$$
\alpha_{i}^{g} R_{i}^{b} k_{i}+\left(1-\alpha_{i}^{g}\right)\left(1-\xi_{i}\right) n_{i}-\mu_{j}\left(k_{i}-\xi_{i} n_{i}\right) \geq\left(1+r_{j}^{b}\right) a_{j}
$$

the participation constraint of depositors

$$
\alpha_{i}^{g} R_{i}^{d} k_{i} \geq\left(1+r_{j}^{h}\right) h_{j}
$$

the feasibility requirement

$$
a_{j}+h_{j}-\mu_{j}\left(k_{i}-\xi_{i} n_{i}\right) \geq k_{i}-\xi_{i} n_{i} .
$$

and the budget constraint

$$
R_{i} \geq R_{i}^{e}+R_{i}^{b}+R_{i}^{h}
$$

First, note that all six equations hold with equality in equilibrium. Second, the interest rate on a loan is defined only implicitly. Note that in the case of success of the project, the joint payoff to the lender and depositors has to be equal to the principal and interest payment

$$
\left(R_{i}^{b}+R_{i}^{h}\right) k_{i}=Z_{i}\left(k_{i}-\xi_{i} n_{i}\right)
$$

where $Z_{i}$ is the gross interest rate paid on the loan. This additional equation allows me to test the model. To derive an interest rate as a function of observable parameters and variables, I use the adequacy ratio $\kappa_{j}$ - that is, lender's equity share in a loan

$$
\frac{a_{j}}{a_{j}+h_{j}}=\kappa_{j}
$$

Scaling all equations by $k_{i}$ and rearranging equations yields

$$
\left(R_{i}^{b}+R_{i}^{d}\right)=\frac{\bar{r}_{j}\left(1+\mu_{j}\right)\left(1-\xi_{i} \frac{1}{L_{i}}\right)+\mu_{j}\left(1-\xi_{i} \frac{1}{L_{i}}\right)-\left(1-\alpha_{i}^{g}\right)\left(1-\xi_{i}\right) \frac{1}{L_{i}}}{\alpha_{i}^{g}}
$$

where $\frac{k_{i}}{n_{i}}=L_{i}$ - the leverage - and $\bar{r}_{j}=\left[\left(1+r_{j}^{b}\right) \kappa_{j}+\left(1+r_{j}^{h}\right)\left(1-\kappa_{j}\right)\right]$ - the weighted average financing cost of the loan. The following section describes the bank balance sheet data that I then use for $r^{h}, r^{b}, \kappa$, and $\mu$ in equations 16 and 18 to derive a model-implied interest rate $Z$. 


\subsection{Banks Data}

The confidential SSBFs include the lender's name. I restrict the matching of firms and financial institutions to banks and credit unions for two purposes. First, models of financing constraints usually consider banks. The second reason is a practical concern. Avaible information for banks is more detailed. Avaible information for leasing companies and car-manufacturer-owned financing companies, however, is sparse as these two type of financial institutions are not subject to the bank regulatory reporting requirements. The latter are typically not deposit-taking institutions and are therefore not subject to the same regulatory requirements for reporting and capital standards.

Table 4 summarizes the bank variables used in the assessment of the MH model. The interest cost, used to proxy for $r^{h}$, and other (noninterest) costs is taken from the banks' income statements in the Call Reports. ${ }^{24}$ The interest cost is measured relative to liabilities minus equity to calculate the average of an additional dollar of external finance to a bank. The other (noninterest) cost to asset ratio - the average cost for one additional dollar of assets on the banks' balance sheets — proxy for monitoring cost $(\mu)$. Return on equity, $\left(r^{b}\right)$, is profit divided by bank equity. The adequacy ratio $(\kappa)$, measuring the composition of a banks financing, is the equity divided by total liabilities. Note that the income and cost variables in the Call Reports are reported as year-to-date and need to be converted to obtain annualized rates. Last, the loan share is defined as the share of loans of total assets. ${ }^{25}$

For the 1998 sample, 493 out of 924 (53 percent) credit contracts could be matched with bank data. ${ }^{26}$ The 493 credit contracts originate from 316 different institutions. Many of the unmatched observations do not include a financial institution's name or were labeled "fake bank" by the interviewer. The second, large group received credit for car manufacturer-owned financing companies, leasing companies, or specialized investors. For firms that were denied credit the match rate is 66 percent (110 out of 166).

For the 2003 sample, the match rate is significantly higher. Here, 1,340 out of 1,693 (79 percent) credit contracts could be matched to financial statements of banks. The 1340 credit contracts involve 613 different institutions. Only a few firm owners did not identify the financial institutions.

\footnotetext{
${ }^{24}$ I pull the crucial bank information from the Call Reports, the Thrifts Financial Reports, and Call Reports for credit unions. These reports are filed by financial institutions on a quarterly basis and include the balance sheet of a financial institution, the income statement, and the regulatory capital ratios. In some case, the bank's name would allow for the identification of individuals in the SSBFs. Since the SSBFs provides detailed private information of firm owners, bank identities are available in the confidential dataset administered by the Federal Reserve Board but not in the public dataset.

${ }^{25}$ The respective variables classification in the Call Report data can be found in the appendix.

${ }^{26}$ The confidential $2003 \mathrm{SSBF}$ data already contain precise matches from interviews for most observations. For the rest, I use the bank's name from the credit contract in the SSBF to retrieve the bank's identifier (RSSD ID) from the National Information Center (NIC). NIC tracks the ownership of banks including all mergers and therefore allows for an accurate identification of banks.
} 
Most of the unmatched observations received financing from car manufacturer-owned financing companies. Of the firms whose credit application was rejected, 72 percent (101 out of 136) were matched to banks.

\subsection{Fitting the MH Contract}

Having concluded that agency problems between borrowers and lenders are an empirically plausible and of economic significance, I now turn to the agency problems between lenders and investors, who in the MH model application to small business lending are bank bond holders and depositors. As a result of agency problem between banks and bank bond holders and depositors, this model focuses on banks' financing costs and balance sheet compositions. As noted in section 3.1, this model does not explicitly specify an interest rate on the loan. The implied interest rate payment can be derived from the sum of the payments to the bank $\left(R^{b}\right)$ and the bank bond holders and depositors $R^{h}$. Recall equations 16 and 18

$$
\left(R_{i}^{b}+R_{i}^{h}\right) L_{i}=Z_{i}\left(L_{i}-\xi_{i}\right)
$$

and

$$
\left(R_{i}^{b}+R_{i}^{h}\right)=\frac{\bar{r}_{j}\left(1+\mu_{j}\right)\left(1-\xi_{i} \frac{1}{L_{i}}\right)+\mu_{j}\left(1-\xi_{i} \frac{1}{L_{i}}\right)-\left(1-\alpha_{i}^{g}\right)\left(1-\xi_{i}\right) \frac{1}{L_{i}}}{\alpha_{i}^{g}}
$$

where $\bar{r}_{j}=\left[\left(1+r_{j}^{b}\right) \kappa_{j}+\left(1+r_{j}^{h}\right)\left(1-\kappa_{j}\right)\right]$ - the weighted average financing cost of the loan. Note that the right-hand side of the last equation contains only variables that can be constructed from the SSBF and Call Reports. As in the assessment of CSV, I use the credit score to proxy for the probability of success $\alpha^{g}$ and the share of fixed assets proxies for the share of collateral $\left(\xi_{i}\right)$. The construction of the rate of return on bank capital $\left(r_{j}^{b}\right)$, interest on deposits $\left(r_{j}^{h}\right)$, the adequacy ratio $\left(\kappa_{j}\right)$, and the monitoring cost $\left(\mu_{j}\right)$ are explained in the previous section.

Figure 3 plots the interest rates paid and the interest rates implied by equation 18 . The top panel show the joint distribution of interest rates for the 1998 data and the bottom panel for the 2003 data. Both graphs omit observations with implied interest rates less than 0 percent or more than 20 percent. The average difference is 3.22 percentage points in the 1998 data and 2.98 percentage points in 2003. The correlation between the actual and the implied interest rate is 0.05 in both samples. Removing 25 outliers - an actual interest rate lower than 4 percent or an implied interest rate higher than 20 percent - increases the correlation to 0.1 in the 1998 sample. However, the same criteria applied to the 2003 yields 5 outliers and reduce the correlation to 0.03. The standard deviation of the implied interest rate (5.78) is substantially larger than the standard deviation in the actual interest rate (1.90) for the 1998 sample. For the 2003 sample, the standard deviations are about the same, 2.35 and 2.68 respectively. 
In light of these these findings, this specification of agency problems between banks and bank bond holders and depositors appears to be inconsistent with the data. There are three potential explanations for the poor performance of this specification of the MH model: 1) bank costs are mismeasured, 2) the bank balance sheets and costs, for instance due to competition, do not matter for small business credit interest rates ${ }^{27}$ or 3 ) the model misspecifies how bank variables affect the interest rate on a credit. To adress the first point, I conduct a number of robustness checks with differenct bank balance sheet measures of agency costs but the correlation remains low. ${ }^{28}$

Next, instead of taking the agency cost from the income statement, I back out the implied agency cost by solving for the monitoring cost $\mu_{j}$ that equalizes the model-implied interest rate and the actual interest rate. The model implies a median monitoring cost of 2.14 percent in 1998 and 5.37 percent in 2003. While 2.14 percent appears to be a reasonable number when compared with the cost measure in table 4, 5.37 percent is close to the maximum. In total, less than 40 percent of the contracts in the two samples imply $\mu \in[0,0.1]$ - that is, monitoring cost between $\$ 0$ and $\$ 100,000$ on a $\$ 1$ million loan, - which, as can been seen from the cost distribution across bank in table 4 , is an arguably wide range.

To assess the other two hypotheses on the importance of agency problems between banks and bank bond holders and depositors, I run reduced-form regressions to explain the loan interest rate. The different agency models highlight the importance of different variables for the loan interest rate. The interest rate in the debt contract with CSV depends on firm-specific parameters and the risk-free rate. To see this, substitute equation 9 in equation 2.

\footnotetext{
${ }^{27}$ Berger and Black (2010) argue that large banks have a competitive advantage in providing collateral-based loans. Since almost all loans are collateralized, small banks can be thought of the competitive fringe.

${ }^{28}$ So far, this exercise assumes that balance sheet and income statement information of the bank allows me to measure banks' financing costs, rate of returns, and monitoring costs accurately. Taking the balance sheet and income statement information from a particular quarter may not adequately reflect the medium- to long-run cost, for instance because of special items in accounting such as write-offs in a given quarter. As a first robustness test, I use an alternative measure of agency cost to deal with these mismeasured costs. Instead of using all "other" (noninterest) costs as a measure of monitoring cost, I use salaries and employee benefits, data processing expenses, legal fees, and insurance assessments only. This measure therefore excludes expenses related to real estate and other fixed assets. Due to data availability, this exercise is done for the 2003 sample only. In the alternative specification the average cost fall to 1.4 percent compared with 2.9 percent when all other costs are considered. Employing this measure of monitoring cost reduces the difference between the model-implied interest rate and the actual interest rate to 40 basis points. However, the correlation remains low (0.06). Removing extreme outliers increases the correlation to 0.07 in the 2003 data. The scatter plot (figure 5) can be found in the appendix. In addition, the standard deviation of the implied interest rate drops to only 1.47, far lower than the standard deviation of the interest rate in the data (2.68). Similarly, using the FDIC's capital-ratio requirements for well-capitalized banks and the appropriate risk weights for business loans instead of actual adequacy ratios yields a 10 percent adequacy ratio under Basel I and a 7.5 percent adequacy ratio under Basel II. Using these two ratios for all banks does not change the results. Next, instead of using the information from one quarter, I average the quarterly data over three years. However, I find no difference to the results with information from one quarter only (see figure 4 in the appendix).
} 


$$
Z_{i}=\frac{\bar{\omega}_{i} R_{i}^{k}\left(1+r \xi_{i}\right)+\left(1-\xi_{i}\right)(1+r)\left(1-G\left(\bar{\omega}_{i}\right) \frac{R_{i}^{k}}{(1+r)}\right)}{1+r \xi_{i}-(1+r)\left(1-G\left(\bar{\omega}_{i}\right) \frac{R_{i}^{k}}{(1+r)}\right)} .
$$

The interest rate on the loan in $\mathrm{MH}$ and more generally in models with agency problems between banks and bank bond holders and depositors depends on firm-specific and on bank-specific parameters. Using equations 16 and 18 yields

$$
Z_{i}=\frac{\bar{r}_{j}\left(1+\mu_{j}\right)+\mu_{j}}{\alpha_{i}^{g}}-\frac{\left(1-\alpha_{i}^{g}\right)}{\alpha_{i}^{g}} \times \frac{\left(1-\xi_{i}\right) \frac{1}{L_{i}}}{\left(1-\xi_{i} \frac{1}{L_{i}}\right)},
$$

with $\bar{r}_{j}=\left[\left(1+r_{j}^{b}\right) \kappa_{j}+\left(1+r_{j}^{h}\right)\left(1-\kappa_{j}\right)\right]$ - the weighted average financing cost of the loan. Hence, in equilibrium, the interest rate is increasing in the financing cost parameters $r_{j}^{b}, r_{j}^{h}$, and $\kappa_{j}$ and decreasing in the quality of the project $\alpha_{j}$.

The regression analysis of the interest rate confirms the hypothesis that bank balance sheets and costs do not matter for small business credit interest rates and, by extension, rejects the third hypothesis that the results presented above were driven by a misspecification of how bank variables affect the interest rate on a credit. Table 5 shows that bank variables have little explanatory power. ${ }^{29}$ The estimates for the bank's decisions to extend credit suggest that banks with assets less than $\$ 50$ billion are more likely to lend to small businesses, however other than bank size no bank balalnce sheet variable was significant in the selection equation (not shown here). ${ }^{30}$ By contrast, firm specific variables are highly significant in the acceptance decision of banks. This finding reflects the empirical plausiblilty of each channel. In models with agency problems between borrowers and lenders, exemplified in CSV, the interest rate is a function of firm variables and the risk-adjusted outside investment opportunities of the bank - conventionally proxied by the risk-free rate. Additional agency problems between banks and bank bond holders and depositors as in $\mathrm{MH}$, however, focuses on the importance of the bank's balance sheets.

On the firm's side, age, size, and the credit score have a strong negative effect on the interest rate. Yet net worth, measured in millions, has only a negligible economic effect. An additional million dollars of net worth reduces the interest rate by 9-14 basis points. Rajan (1992) points out that longer lending relationships result in informational monopolies, which is especially true for small businesses. Banks also may try to attract new customers with teaser rates on the first loan and raise the interest rate on subsequent loans. The positive and significant coefficient on

\footnotetext{
${ }^{29}$ Excluding quarterly dummies yields highly significant estimates of the interest cost, -24.95 basis points for the 1998 sample and 43.52 basis points in the 2003 sample, which may be due to difference in the federal funds rate over the sample period. The lattertranslates to a 43.5 basis point increase on the credit interest rate in response to a 100 basis point increase in the cost of funding for the bank.

${ }^{30}$ The results do not change when setting the bank size threshold to $\$ 10$ billion, which the SBLF threshold for community banks.
} 
the length of the relationship in the 2003 sample supports this view. There appears to be no relationship effect in the $1998 \mathrm{SSBF}$ sample. However, the lack of an relationship effect may be the result of the omission of credit renewals, which biases the 1998 sample.

One potential source of bias arises from differences in local economic conditions, which are important assess the riskiness of a small business. The regressions, therefore, include the fraction of late and nonaccrual loans, which, at least for smaller banks, is a plausible proxy for differences in local economic conditions. In fact, in most regressions the share of loans that is 90 day past due has a significant positive effect on the loan's interest rate (not shown here). Using the alternative cost measures described above confirms the findings from the regression analysis (see appendix).

It cannot be excluded that there may be additional measurement errors in the rate of return of a bank or the proxies for agency cost, but it is hard to imagine that such measurement errors are correlated with covariates in way that would overturn the key finding of the section. Contrary with a model with agency problems between banks and bank bond holders and depositors, bank variables lack explanatory power for the interest rate of the loan.

\section{Reduced-Form Financing Constraints}

Frictionless capital markets imply an undetermined capital structure of firms, and no systematic relationship between net worth and credit emerges. However, some firms use a decreasing economies of scale technology that limits optimal firm size. In those cases, everything else equal, firms with higher net worth should take on less credit as they are closer to the optimal size. Here, when capital markets are frictionless, a negative relationship between net worth and the credit amount should be observed in the data.

The defining deviation from frictionless capital markets - and one that I will verify empirically - is that both agency problems described above imply a positive relationship between net worth and the credit amount. In particular, the credit amount is some multiple of net worth. Using the definition of debt and leverage in CSV in equation 9 yields

$$
d_{i}=\frac{1-\xi_{i}+\left(G\left(\bar{\omega}_{i}\right) \frac{R_{i}^{k}}{(1+r)} \xi_{i}\right)(1+r)}{(1+r)\left(1-G\left(\bar{\omega}_{i}\right) \frac{R_{i}^{k}}{(1+r)}\right)} n_{i} .
$$

In the MH model, the relationship of net worth and loans, which I will assess in the next section, can be derived using equations $10,11,13,14,15$, and 17 . For simplicity, assume $\xi=1$.

$$
d_{i}=\frac{\frac{\mu_{j}}{\alpha_{i}^{g}-\alpha_{i}^{b}}+\alpha_{i}^{g}\left(R_{i}-\frac{b_{i}+\mu_{j}}{\alpha_{i}^{g}-\alpha_{i}^{b}}\right)}{\left(1+r_{j}^{h}\right)\left(1-\kappa_{j}\right)\left(1+\mu_{j}\right)-\alpha_{i}^{g}\left(R_{i}-\frac{b_{i}+\mu_{j}}{\alpha_{i}^{g}-\alpha_{i}^{b}}\right)} n_{i}
$$


The derivation can be found in the appendix C. Note that according to the $\mathrm{MH}$ model, in equilibrium, debt should be higher for projects with higher success probability $\left(\alpha_{i}^{g}\right)$, for projects with higher gross rates of return $\left(R_{i}\right)$, for banks with low financing cost $r_{j}^{h}$, and for projects with a higher bank share of funding $\left(\kappa_{j}\right)$. The latter is due to the fact that with an agency problem between banks and bank bond holders and depositors the model leverages net worth of the entrepreneur and the net equity of the financial intermediary. As for the interest rate, the underlying agency problems of models differ on the importance of bank-specific variables.

Equations 21 and 22 show that debt contract models imply that for the firms that received credit the credit amount is some multiple of net worth $n_{i}$ :

$$
d_{i}=\varphi n_{i}
$$

where $d_{i}$ is the credit amount of entrepreneur $i$ and $\varphi$ the net worth multiplier. Reduced-form financing constraints of this form are also commonly used in the literature on entrepreneurship, for instance in Evans and Jovanovic (1989), Cagetti and de Nardi (2006), and Buera (2009). I test this relationship in the small business data. Clearly, not all firms in need of external finance receive credit and the SSBFs provide indicators of a firm's success in obtaining credit. ${ }^{31}$ Hence, the regression analysis takes selection into account.

Roughly one-fifth of all firms in the 1998 sample and about one-third of all firms in the 2003 sample obtained credit. This large difference is due to the fact that the 1998 sample explicitly excluded renewals of lines of credit. This clearly introduces a selection bias towards 1) more denials and 2) younger and smaller firms receiving credit (see Table 1).

As equations 21 and 22 show, the net worth multiplier $\varphi$ depends on the riskiness, bankruptcy cost, and the rate of return of a project, each of these parameter can be differ across projects. Second, net worth may be measured with error. This implies the following estimation equation

$$
d_{i}=\alpha+\beta n_{i}+\epsilon_{i}
$$

The agency model suggests $\beta>0$. In the regressions, credit amount and net worth are measured in millions. Table 6 summarizes the results for the full sample 1998 and 2003. The credit amount and net worth exhibit a strong, positive relationship. An additional dollar of net worth accounts for 30 cents of additional external finance. The variation in net worth explains the variation in credit

\footnotetext{
${ }^{31}$ The first measure is whether firms applied for credit when they were in need of credit. In particular, both samples identify firms reporting that were in need of credit, but decided against applying for a loan as they feared denial. A general pattern emerges. First, young firms are less likely to apply for credit, and their applications are turned down more frequently. Second, not all credit applications were granted by financial institutions. Not being able to obtain (additional) external finance, these firms have to finance investment with internal resources only. Levenson and Willard (2000), Kon and Storey (2003) and Meisenzahl (2010) discuss this type of credit rationing in more detail.
} 
amounts well ( $R^{2}$ of 0.29 and 0.27 ). Measurement error in $n_{i}$ may bias the estimator downwards. The second and the fifth column show the results after controlling for firm size as a proxy for the differences in the rate of return. The point estimates for the net worth multiplier barely change. In line with the prediction of heterogeneity in the rate of return, firm size affects the credit amount positively. Not all credit applications were accepted. Hence, the OLS estimators are potentially subject to a selection bias. The selection model estimates, columns 3 and 6 in table 6 , show that selection not a concern in the analysis.

The SSBF data provide a rich set of additional control variables for sources of heterogeneity: the credit score of the firm, previous bankruptcy, census region, industry, and organizational form. The credit score, judgments against the firm, and previous private and firm bankruptcies proxy for differences in risk. Regional and industry dummies control for differences in risk and rate of return in these dimensions. While there is evidence in the 1998 sample that firms with a solid financial history received more credit, no effect of credit scores on credit amounts is present in the 2003 sample. Due to a lack of variation in the 1998 sample, judgments and previous private and firm bankruptcies can only be used in the 2003 sample. Judgments have a strong negative effect, while previous bankruptcies exhibit no significant effect. Firms with judgments already pending are more risky. The negative effect of judgments on the credit amount is in line with the prediction of lower leverage for higher risk firms. Due to differences in liability, the variation in the legal form of the firms proxies for differences in bankruptcy cost. However, in both samples the legal form has no significant effect. This is consistent with the fact that half of the sample provided personal guarantees, and therefore limited liability of the firm has little effect. Bank variables described above have no significant effect on the credit amount.

As table 7 shows, employing this large set of controls does not yield significantly different results for the estimated effect of net worth. Again controlling for selection does not change the results. Bank regulatory capital ratios were used as exclusion restrictions in the selection equation as undercapitalized banks (in a regulatory sense) cut back lending to bank-dependent borrowers (Hancock and Wilcox, 1993).

Section 2.2 argues that in the context of small businesses, a wider definition of net worth is appropriate. To ensure that the results are not solely the result of the definition of net worth, I consider three additional definitions consistent with the pattern of collateral offered. Since equipment accounts for almost half of collateral offered, we always include depreciable assets in our definitions: 1) firm's assets less firm's liabilities, 2) firm's depreciable assets, land, building, and net value of private residence less firm's loans, and 3) firm's depreciable assets, land, buildings, and net value of private residence less firm's liabilities. The narrower definitions of net worth also yield a robust positive credit amount-net worth, relationship but the explanatory power of net 
worth is substantially reduced in some regressions (see tables 12-14 in the appendix).

Receiving less credit than applied for is another possible constraint. The SSBFs explicitly ask for the loan amount applied for and the loan amount received. Over 90 percent of small business owners report that the loan amount they received was equal to the loan amount they applied for. While it cannot be excluded that the loan amount on the application was agreed upon informally prior to the application, there is no indication in the surveys that firms do not receive the desired loan amount.

Consistent with models of financing constraints considered here, net worth and the credit amount exhibit a robust positive relationship. In the SSBF data, an additional dollar of net worth accounts for 30 cents of additional external finance. In comparison, in their model of entrepreneurship, Evans and Jovanovic (1989), using the National Longitudinal Survey of Young Men, estimate the effect to be 44 cents of external finance for an additional dollar of net worth while Cagetti and de Nardi (2006) calibrate the effect to roughly 67 cents for entrepreneurs to match the U.S. wealth distribution. ${ }^{32}$ However, contrary with agency problems between banks and bank bond holders and depositors, bank variables do not matter for the credit amount.

\section{$5 \quad$ Small vs Large Banks}

This section examines difference between small and large banks to ensure that the results presented in the previous section are not driven by large financial institutions. The latter are more diversified, and therefore their balance sheet information may be less precise in measuring the variables of interest.

It is worthwhile to note that small businesses tend to use with small banks. The 1998 sample shows little evidence of dominance by large banks in the small business lending market. In sum, for all banks whose market share exceeds 1 percent, I find that 6 banks account for 23 percent (19 percent using firm weights in the SSBF) of all credit contracts and 31 percent (32 percent weighted) of denials in the sample. In the 2003 sample there is more concentration, but that was to be expected, as the banking industry continued to consolidate. Here, 11 banks have at least 1 percent of the market. Together large banks account for 30 percent (23 percent weighted) of the credit contracts by banks. They also account for 38 percent (44 percent weighted) of denials. Large banks, when defined as systemically important banks in the Dodd-Frank Act (banks with more than $\$ 50$ billion assets), account for about one-third of all credit contracts(and also roughly one-third when measured by total credit amount) and for almost 40 percent of credit denial). Lowering the threshold to $\$ 10$ billion as in the SBLF policy does not change the results of this section.

\footnotetext{
${ }^{32}$ Buera (2009) estimates a broader range from 10 cents to $\$ 3$.
} 
Table 8 shows that there are only minor differences between small businesses who decide to bank with small banks and those who bank with large banks. Perhaps the most striking difference is that small business owners who bank with large banks tend to have more equity.

First, I report the result for the credit amount regressions by bank size. Since selection has no significant effect I omit the results in table 9. The main result, the importance of net worth, does not change. While the point estimates for the 2003 sample are the same for small and large banks, they differ significantly for the 1998 sample.

Second, I explore whether there are differences by bank size with respect to interest rates. Tables 10 and 11 summarize the results for the 1998 and 2003 sample. With the exception of the interest cost, which contrary to $\mathrm{MH}$ model enter negatively, no significant differences arise in the 1998 sample. Firm variables, such as size and sectoral dummies, appear to be more important.

In contrast, the 2003 sample in table 11 exhibits sharp differences. Here bank balance sheet information is important in the subsample of large banks, albeit the point estimate of cost measure is negative and weakly significant. A 100 basis point difference in the financing cost of large banks increases the interest rate on a small business loan by more than 250 basis points. This result may reflect the increasing concentration in the banking industries, which leaves large banks with more market power. Yet large banks still serve less than one-third of the market. For small banks, however, bank variables are not significant, even though they are arguably closer to a standard model of banks than large financial conglomerates. In contrast to the implications of agency problems between banks and bank bond holders and depositors, this result supports a more competitive banking market model. For instance, small banks can be seen as the competitive fringe to an oligopoly.

\section{Conclusion}

This paper exploits business credit contracts and the net worth of entrepreneurs to examine which model of financing constraints most accurately describes small business lending market. The analysis focuses on two commonly used agency problems that motivate financing constraints one between entrepreneurs and banks and one between the bank and the bank's depositors and bond holders - that are the building blocks of the costly state verification model by Townsend (1979) and the moral hazard in monitoring model by Holmström and Tirole (1997). The CSV model can rationalize more than two-thirds of the credit contracts in the data. Bankruptcy costs, implied by small business credit contracts when fitting the CSV debt contracts, are 28 percent of expected output and the implied rate of return lies between 5 percent and 8 percent annually. Thus, the underlying agency problem between entrepreneurs and banks, and thereby the implied 
"firm balance sheet channel," are empirically plausible. The agency costs stemming from moral hazard problems between bank and the outside investors implied by the MH model are between 2-5 percent but less than 40 percent of the contracts in the two samples yield plausible agency cost. More generally, this type of agency problem, which results in a "bank balance sheet channel," emphasizes the importance of bank variables for loan pricing and the loan amount, a hypothesis that does not hold in small business loan contracts.

What are the consequences of these results for policymakers? Since bank variables have little effect on loan contracts, providing additional funding to banks may not be effective, which is consistent with the literature that reports only small effects of capital ratios on loan supply (Berrospide and Edge, 2010). Banks that are willing to lend in the aftermath of the Great Recession face entrepreneurs whose balance sheets, due to the drop in house prices, are in need of repair. Simply put, entrepreneurs lack sufficient collateral, which increases agency cost between banks and entrepreneurs and reduces lending to small businesses. Policies seeking to improve current and potential future entrepreneurs' balance sheets, for instance by supporting loan modifications, may be more effective in stimulating lending to small businesses.

\section{References}

Alti, Aydogan. 2003. "How Sensitive Is Investment to Cash Flow When Financing Is Frictionless?" Journal of Finance 58 (2):707-722.

Berger, Allen and Gregory Udell. 1998. "The Economics of Small Business Credit Finance: The Role of Private Equity and Debt Markets in the Financial Growth Cycle." Journal of Banking and Finance 22 (6-8):613-673.

Berger, Allen N. and Lamont K. Black. 2010. "Bank Size, Lending Technologies, and Small Business Finance." Journal of Banking and Finance forthcoming.

Berkowitz, Jemery and Michelle J. White. 2004. "Bankruptcy and Small Firms' Access to Credit." Rand Journal of Economics 35 (1):69-84.

Bernanke, Ben S. and Mark Gertler. 1989. "Agency Costs, Net Worth, and Business Fluctuations." American Economic Review 79 (1):14-31.

Bernanke, Ben S., Mark Gertler, and Simon Gilchrist. 1999. "The Financial Accelerator in a Quantitative Business Cycle Framework." In Handbook of Macroeconomics, edited by John Taylor and Michael Woodford. Amsterdam, New York and Oxford: Elsevier Science, NorthHolland, 1341-1393. 
Berrospide, Jose M. and Rochelle M. Edge. 2010. "The Effects of Bank Capital on Lending: What Do We Know, and What Does It Mean?" Finance and Economics Discussion Series 2010-44.

Bitler, Marianne, Alicia Robb, and John Wolken. 2001. "Financial Services Used by Small Businesses: Evidence from the 1998 Survey of Small Business Finances." Federal Reserve Bulletin $87: 183-205$.

Buera, Francisco J. 2009. "A Dynamic Model of Entrepreneurship with Borrowing Constraints: Theory and Evidence." Annals of Finance 5 (3-4):443-464.

Cagetti, Marco and Mariacristina de Nardi. 2006. "Entrepreneurship, Frictions, and Wealth." Journal of Political Economy 114 (5):835-870.

Calem, Paul, Francisco Covas, and Jason Wu. 2011. "The Impact of a Liquidity Shock on Bank Lending: The Case of the 2007 Collapse of the Private-Label RMBS Market." manuscript, Federal Reserve Board.

Carlstrom, Charles and Timothy Fuerst. 1997. "Agency Costs, Net Worth, and Business Fluctuations: A Computable General Equilibrium Analysis." American Economic Review 87 (5):893-910.

Cavalluzzo, Ken and John Wolken. 2005. "Small Business Loan Turnovers, Personal Wealth and Discrimination." Journal of Business 78 (6):2153-2177.

Chava, Sudheer and Michael R. Roberts. 2008. "How Does Financing Impact Investment? The Role of Debt Covenants." Journal of Finance 63 (5):2085-2121.

Chen, Nan-Kuang. 2001. "Bank Net Worth, Asset Prices and Economic Activity." Journal of Monetary Economics 48 (2):415 - 436.

Christensen, Ian and Ali Dib. 2008. "The Financial Accelerator in an Estimated New Keynesian Model." Review of Economic Dynamics 11 (1):155-178.

Christiano, Lawrence J., Roberto Motto, and Massimo Rostagno. 2007. "Financial Factors in Business Cycles." manuscript, Northwestern University.

Cooley, Thomas F. and Vincenzo Quadrini. 2001. "Financial Markets and Firm Dynamics." American Economic Review 91 (5):1286-1310.

Covas, Francisco and Wouter J. den Haan. 2011. "The Role of Debt and Equity Finance over the Business Cycle." American Economic Review 101 (2):877-899. 
Cummins, Jason G., Kevin A. Hassett, and Stephen D. Oliner. 2006. "Investment Behavior, Observable Expectations, and Internal Funds." American Economic Review 96 (3):796-810.

Evans, David and Boyan Jovanovic. 1989. "Estimates of a Model of Entrepreneurial Choice under Liquidity Constraints." Journal of Political Economy 97 (4):808-827.

Fazzari, Steven M., R. Glenn Hubbard, and Bruce C. Petersen. 1988. "Financing Constraints and Corporate Investment." Brookings Papers on Economic Activity 1988 (1):141-206.

Fisher, Jonas D. M. 1999. "Credit Market Imperfections and the Heterogeneous Response of Firms to Monetary Shocks." Journal of Money, Credit and Banking 31 (2):187-211.

Gale, Douglas and Martin Hellwig. 1985. "Incentive-Compatible Debt Contracts: The One-Period Problem." Review of Economic Studies 52 (4):647-663.

Giambona, Erasmo and Armin Schwienbacher. 2008. "Debt Capacity of Tangible Assets: What is Collateralizable in the Debt Market?" manuscript, University of Amsterdam.

Gilchrist, Simon, Alberto Ortiz, and Egon Zakrajšek. 2009. "Credit Risk and the Macroeconomy: Evidence from an Estimated DSGE Model." manuscript, Boston University.

Gomes, Joao F. 2001. "Financing Investment." American Economic Review 91 (5):1263-1285.

Haltiwanger, John C., Ron Jarmin, and Javier Miranda. 2010. "Who Creates Jobs? Small vs. Large vs. Young." NBER Working Paper 16300.

Hancock, Diana and James A. Wilcox. 1993. "Has There Been a 'Credit Crunch' in Banking? The Effects of Bank Lending on Real Estate Market Conditions and Bank Capital Shortfalls." Journal of Housing Economics 3 (1):31-50.

Hart, Oliver and John Moore. 1994. "A Theory of Debt Based on the Inalienability of Human Capital." Quarterly Journal of Economics 109 (4):841-879.

Hennessy, Christopher and Toni Whited. 2007. "How Costly is External Financing? Evidence from a Structural Estimation." Journal of Finance 62 (4):1705-1745.

Holmström, Bengt and Jean Tirole. 1997. "Financial Intermediation, Loanable Funds, and the Real Sector." Quarterly Journal of Economics 112 (3):663-691.

Kaplan, Steven N. and Luigi Zingales. 2000. "Investment-Cash Flow Sensitivities Are Not Valid Measures of Financing Constraints." Quarterly Journal of Economics 115 (2):707-712. 
Kiyotaki, Nobuhiro and John Moore. 1997. "Credit Cycles." Journal of Political Economy $105(2): 211-248$.

Kon, Y. and D. J. Storey. 2003. "A Theory of Discouraged Borrowers." Small Business Economics $21(1): 37-49$.

Levenson, Alec and Kristen Willard. 2000. "Do Firms Get What They Want? Measuring Credit Rationing Experience by Small Business in the U.S." Small Business Economics 14 (1):83-94.

Levin, Andrew, Fabio Natalucci, and Egon Zakrajšek. 2004. "The Magnitude and Cyclical Behavior of Financial Market Frictions." Finance and Economics Discussion Series 2004-70.

Mach, Traci and John Wolken. 2006. "Financial Services Used by Small Businesses: Evidence from the 2003 Survey of Small Business Finances." Federal Reserve Bulletin 92:A167-A195.

Masulis, Ronald W. 1988. The Debt / Equity Choice. Cambridge: Ballinger Publishing Company.

Meh, Cesaire A. and Kevin Moran. 2010. "The Role of Bank Capital in the Propagation of Shocks." Journal of Economic Dynamics and Control 34 (3):555-576.

Meisenzahl, Ralf R. 2010. "Financing Constraints and the Evolution of Firm Size Distribution: New Evidence From U.S. Small Businesses." manuscript, Federal Reserve Board.

Moskowitz, Tobias J. and Annette Vissing-Jørgensen. 2002. "The Returns to Entrepreneurial Investment: A Private Equity Premium Puzzle?" American Economic Review 92 (4):745-778.

Nolan, Charles and Christopher Thoenissen. 2009. "Financial Shocks and the U.S. Business Cycle." Journal of Monetary Economics 56 (4):596-604.

Paulson, Anna L., Robert M. Townsend, and Alexander Karaivanov. 2006. "Distinguishing Limited Liability from Moral Hazard in a Model of Entrepreneurship." Journal of Political Economy $114(1): 100-144$.

Rajan, Raghuram G. 1992. "Insiders and Outsiders: The Choice between Informed and Arm'sLength Debt." Journal of Finance 47 (4):1367-1400.

Stiglitz, Joseph and A. Weiss. 1981. "Credit Rationing in Markets with Imperfect Information." American Economic Review 71 (3):393-410.

Sufi, Amir. 2007. "Information Asymmetry and Financing Arrangements: Evidence from Syndicated Loans." Journal of Finance 62 (2):629-669. 
Sullivan, Teresa A., Elizabeth Warren, and Jay Lawrence Westbrook. 1989. As We Forgive Our Debtors: Bankruptcy and Consumer Credit in America. New York: Oxford University Press.

Townsend, Robert. 1979. "Optimal Contracts and Competitive Markets with Costly State Verification." Journal of Economic Theory 21 (2):265-293.

von Heideken, Virginia Q. 2009. "How Important are Financial Frictions in the U.S. and the Euro Area?" Scandinavian Journal of Economics 111 (3):567-596.

Wasmer, Etienne and Phillipe Weill. 2004. "The Macroeconomics of Labor and Credit Market Imperfections." American Economic Review 94 (4):944-964. 


\section{Appendix A - Data}

\section{Construction of Bank Variables}

Bank variables from the Call Reports for commerical banks (RIAD, RCON), thrifts (SVGL), and credit unions (CUSA):

- bank capital a from RIAD3210, SVGL3491, and CUSA3210 - bank equity

- deposits $h$ - for commercial banks: sum of RCON6631 (non-interest bearing deposits), RCON6636 (interest bearing deposits), RCONb993 (Fed funds purchased), RCONb995 (Securities sold, repurchase), RCON3548 (Trading Liabilities), and RCON3190 (other borrowed money), for thrifts: SVGL2339+SVGL2071 (Deposits and Escrows), after 2003Q4 SVGLC503 and SVGL3101 (other borrowing), and for credit unions CUSA4584 (borrowings), CUSA2302 (non-member deposits), and CUSA3139 (shares).

- bank's outside rate of return $r^{b}$ - Return on Equity. RIAD4340 (Net Income) divided by RIAD3210 (bank equity), SVGL4340/SVGL3491, and CUSA4273/CUSA3210.

- depoistor's outside rate of return $r^{h}$ - RIAD4073, SVGL0481, CUSA4073 (Total interest rate expense) divided by $h$,

- monitoring cost $\mu$ - RIAD4093, sum of SVGL4141, SVGL0495, SVGL4154, SVGL0499, CUSA4093 (non-interest expense) divided by total assets (here $h$ and equity).

Other variables in regressions

- share of loans 30-90 days late, over 90 days late and non-accrual. RCFD1406, RCFD1407, RCFD1403 divided by RCON1400; SVGL3936, SVGL3942, and SVGL3948 divided by SVGL1576(non-mortgage)+SVGL0446(Mortgage) and CUSA1128 (30-60 days), CUSA1125 (60-120 days) and CUSA1127 divided by CUSA1263.

- Risk-Based Capital Ratio RCFD7205, SVCC7205, for unions only CUSA7276 risk-based net worth ratio. 


\section{Appendix B - Robustness}

To ensure that the results in section 4 are not driven only by the definition of net worth, I provide the regression results for various other definitions of net worth.

The definition employed in the regression in table 12 follows Giambona and Schwienbacher (2008). They argue that only hard tangible assets can be used as collateral. Hence, in table 12, net worth is defined as the sum of land, depreciable assets, and the net value of the private residence minus loans. While net worth is still significant in all regressions, the explanatory power of net worth is greatly reduced relative the baseline definition.

Table 13 displays the results of a different definition of net worth in the spirit of Giambona and Schwienbacher (2008). Instead of subtracting loans only, all firm liabilities are subtracted from the sum of land, depreciable assets, and the net value of the private residence to calculate net worth. Again, the explanatory power of net worth is reduced relative to the baseline definition, but the results are still significant.

The last robustness check with respect to the definition of net worth uses the firm balance sheet only. In table 14 , net worth is defined as all firm assets minus all firm liabilities. The results are comparable with the baseline definition in terms of explanatory power, yet the point estimates are slightly higher. 


\section{Appendix C - Derivation of Leverage in MH}

Assume $\xi=1$. Rewriting yields equations 10 and 11

$$
R_{i}^{e}=\frac{b}{\alpha_{i}^{g}-\alpha_{i}^{b}}
$$

and

$$
R_{i}^{b}=\frac{\mu_{j}\left(1-L_{i}\right)}{\alpha_{i}^{g}-\alpha_{i}^{b}}
$$

Using the budget constraint $R_{i}=R_{i}^{e}+R_{i}^{b}+R_{i}^{h}$, equation 13 becomes

$$
\alpha_{i}^{g}\left(R_{i}-\frac{b}{\alpha_{i}^{g}-\alpha_{i}^{b}}-\frac{\mu_{j}\left(1-L_{i}\right)}{\alpha_{i}^{g}-\alpha_{i}^{b}}\right)=\left(1+r_{j}^{h}\right) h_{j} .
$$

Next, replacing $h_{j}$, using equation 14 and the definition of the adequacy ratio, yields

$$
\alpha_{i}^{g}\left(R_{i}-\frac{b}{\alpha_{i}^{g}-\alpha_{i}^{b}}-\frac{\mu_{j}\left(1-L_{i}\right)}{\alpha_{i}^{g}-\alpha_{i}^{b}}\right)=\left(1+r_{j}^{h}\right)\left(1-\kappa_{j}\right)\left(1+\mu_{j}\right)\left(1-L_{i}\right) .
$$

Solving for $\frac{1}{L_{i}}=\frac{k_{i}}{n_{i}}$ gives

$$
\frac{k_{i}}{n_{i}}=\frac{\frac{\mu_{j}}{\alpha_{i}^{g}-\alpha_{i}^{b}}+\left(1+r_{j}^{d}\right)\left(1-\kappa_{j}\right)\left(1+\mu_{j}\right)}{\left(1+r_{j}^{h}\right)\left(1-\kappa_{j}\right)\left(1+\mu_{j}\right)-\alpha_{g}\left(R-\frac{b+\mu_{j}}{\alpha_{i}^{g}-\alpha_{i}^{b}}\right)} .
$$

Hence,

$$
d_{i}=\frac{\frac{\mu_{j}}{\alpha_{i}^{g}-\alpha_{i}^{b}}+\alpha_{i}^{g}\left(R_{i}-\frac{b_{i}+\mu_{j}}{\alpha_{i}^{g}-\alpha_{i}^{b}}\right)}{\left(1+r_{j}^{h}\right)\left(1-\kappa_{j}\right)\left(1+\mu_{j}\right)-\alpha_{i}^{g}\left(R_{i}-\frac{b_{i}+\mu_{j}}{\alpha_{i}^{g}-\alpha_{i}^{b}}\right)} n_{i} .
$$


Table 1: Summary Statistics - Firm Variables

\begin{tabular}{|c|c|c|c|c|c|c|c|c|c|c|}
\hline & \multicolumn{5}{|c|}{1998} & \multicolumn{5}{|c|}{2003} \\
\hline & mean & std & $25 \%$ & $50 \%$ & $75 \%$ & mean & std & $25 \%$ & $50 \%$ & $75 \%$ \\
\hline Number of Employees & 12.8 & 28.9 & 2.0 & 5.0 & 11.0 & 15.0 & 31.5 & 3.0 & 6.0 & 13.0 \\
\hline Firm Age & 11.6 & 8.7 & 5.0 & 10.0 & 16.0 & 15.3 & 11.3 & 7.0 & 13.0 & 22.0 \\
\hline Length of Lending Relationship & 7.0 & 8.1 & 1.6 & 4 & 9.1 & 10.1 & 9.1 & 3.6 & 7.0 & 14.5 \\
\hline Credit Score $^{a}$ & 2.9 & 1.1 & 2.0 & 3.0 & 4.0 & 3.7 & 1.5 & 3.0 & 4.0 & 5.0 \\
\hline Net Worth (in mill.) & 0.39 & 1.3 & 0.05 & 0.12 & 0.34 & 0.72 & 2.1 & 0.11 & 0.27 & 0.62 \\
\hline
\end{tabular}

Firm observations weighted with SSBF weights.

$a$ The credit score in 1998 goes from 1 (lowest) to 5 (highest) and in 2003 from 1 (lowest) to 6 (highest). 
Table 2: Net Worth and Equity Share of Assets by Firm Age

\begin{tabular}{|c|c|c|c|c|c|c|c|c|}
\hline \multirow[b]{3}{*}{ Age } & \multicolumn{2}{|c|}{ all firms } & \multicolumn{2}{|c|}{ received credit } & \multicolumn{2}{|c|}{ all firms } & \multicolumn{2}{|c|}{ received credit } \\
\hline & $\begin{array}{l}\text { Number } \\
\text { of obs. }\end{array}$ & $\begin{array}{l}\text { Net Worth } \\
\text { (in mill.) } \\
\text { average } \\
\text { (median) }\end{array}$ & $\begin{array}{l}\text { Number } \\
\text { of obs. }\end{array}$ & $\begin{array}{c}\text { Net Worth } \\
\text { (in mill.) } \\
\text { average } \\
\text { (median) }\end{array}$ & $\begin{array}{l}\text { Number } \\
\text { of obs. }\end{array}$ & $\begin{array}{c}\text { Equity } \\
\text { Share } \\
\text { average } \\
\text { (median) }\end{array}$ & $\begin{array}{c}\text { Number } \\
\text { of obs. }\end{array}$ & $\begin{array}{c}\text { Equity } \\
\text { Share }^{a} \\
\text { average } \\
\text { (median) }\end{array}$ \\
\hline & (1) & $(2)$ & (3) & (4) & (5) & (6) & (7) & (8) \\
\hline$<3$ & 573 & $\begin{array}{c}0.245 \\
(0.092)\end{array}$ & 113 & $\begin{array}{c}0.222 \\
(0.115)\end{array}$ & 574 & $\begin{array}{c}63.7 \% \\
(86.6 \%)\end{array}$ & 113 & $\begin{array}{c}61.8 \% \\
(86.5 \%)\end{array}$ \\
\hline $3-6$ & 1507 & $\begin{array}{c}0.303 \\
(0.106)\end{array}$ & 384 & $\begin{array}{c}0.437 \\
(0.140)\end{array}$ & 1508 & $\begin{array}{c}60.1 \% \\
(76.4 \%)\end{array}$ & 385 & $\begin{array}{c}64.7 \% \\
(81.4 \%)\end{array}$ \\
\hline $7-15$ & 2522 & $\begin{array}{c}0.361 \\
(0.151)\end{array}$ & 761 & $\begin{array}{c}0.544 \\
(0.225)\end{array}$ & 2525 & $\begin{array}{c}65.7 \% \\
(85.0 \%)\end{array}$ & 761 & $\begin{array}{c}63.8 \% \\
(80.5 \%)\end{array}$ \\
\hline $16-25$ & 1784 & $\begin{array}{c}0.508 \\
(0.225)\end{array}$ & 630 & $\begin{array}{c}0.725 \\
(0.316)\end{array}$ & 1785 & $\begin{array}{c}70.7 \% \\
(85.4 \%)\end{array}$ & 630 & $\begin{array}{c}69.3 \% \\
(84.3 \%)\end{array}$ \\
\hline$>25$ & 1404 & $\begin{array}{c}0.801 \\
(0.275)\end{array}$ & 516 & $\begin{array}{c}1.240 \\
(0.443)\end{array}$ & 1406 & $\begin{array}{c}73.8 \% \\
(92.0 \%)\end{array}$ & 517 & $\begin{array}{c}76.0 \% \\
(92.1 \%)\end{array}$ \\
\hline Total & 7790 & $\begin{array}{c}0.432 \\
(0.159)\end{array}$ & 2404 & $\begin{array}{c}0.645 \\
(0.230)\end{array}$ & 7798 & $\begin{array}{c}66.6 \% \\
(84.7 \%)\end{array}$ & 2406 & $\begin{array}{c}67.5 \% \\
(84.4 \%)\end{array}$ \\
\hline
\end{tabular}

Source: SSBF 1998 and 2003. For the construction of net worth, see text.

${ }^{a}$ Equity share before most recent credit was taken out. 
Table 3: Distribution of Fitted Parameters

\begin{tabular}{|c|c|c|c|c|c|c|c|}
\hline & \multicolumn{7}{|c|}{1998 Sample } \\
\hline & mean & med & std & $\min$ & $25 \%$ & $75 \%$ & $\max$ \\
\hline \multicolumn{8}{|l|}{ all obs. } \\
\hline$\mu$ & 1.08 & 0.29 & 2.62 & -13.72 & 0.25 & 0.32 & 23.7 \\
\hline$\sigma$ & 0.54 & 0.59 & 0.25 & 0.01 & 0.39 & 0.67 & 1.21 \\
\hline$R^{k}$ & 1.04 & 1.02 & 0.05 & 0.90 & 1.01 & 1.03 & 1.40 \\
\hline \multicolumn{8}{|l|}{$\mu \in[0,1]$} \\
\hline$\mu$ & 0.28 & 0.28 & 0.09 & 0.01 & 0.24 & 0.31 & 0.96 \\
\hline$\sigma$ & 0.57 & 0.63 & 0.25 & 0.01 & 0.48 & 0.72 & 1.21 \\
\hline$R^{k}$ & 1.02 & 1.02 & 0.01 & 1.01 & 1.01 & 1.02 & 1.10 \\
\hline & \multicolumn{7}{|c|}{2003 Sample } \\
\hline & mean & med & std & $\min$ & $25 \%$ & $75 \%$ & $\max$ \\
\hline \multicolumn{8}{|l|}{ all obs. } \\
\hline$\mu$ & 1.60 & 0.30 & 3.35 & -1.29 & 0.26 & 0.79 & 27.90 \\
\hline$\sigma$ & 0.54 & 0.58 & 0.22 & 0.01 & 0.40 & 0.70 & 1.32 \\
\hline$R^{k}$ & 1.04 & 1.01 & 0.07 & 0.97 & 1.00 & 1.06 & 1.80 \\
\hline \multicolumn{8}{|l|}{$\mu \in[0,1]$} \\
\hline$\mu$ & 0.28 & 0.28 & 0.10 & 0.01 & 0.25 & 0.31 & 0.99 \\
\hline$\sigma$ & 0.57 & 0.64 & 0.24 & 0.01 & 0.47 & 0.72 & 1.18 \\
\hline$R^{k}$ & 1.01 & 1.01 & 0.01 & 1.00 & 1.00 & 1.01 & 1.11 \\
\hline
\end{tabular}

Note: The full 1998 sample consists of 599 observations. The truncated sample has 485 observations. The full 2003 sample consists of 1,413 observations. The truncated sample has 1,079 observations. For a discussion, see text. 
Table 4: Summary Statistics - Bank Variables

\begin{tabular}{|c|c|c|c|c|c|c|c|c|c|c|}
\hline & \multicolumn{5}{|c|}{1998} & \multicolumn{5}{|c|}{2003} \\
\hline & mean & std & $25 \%$ & $50 \%$ & $75 \%$ & mean & std & $25 \%$ & $50 \%$ & $75 \%$ \\
\hline Interest Cost to Liability Ratio ${ }^{a}$ & 0.035 & 0.012 & 0.031 & 0.035 & 0.038 & 0.013 & 0.005 & 0.010 & 0.012 & 0.017 \\
\hline Other Cost to Asset Ratio ${ }^{a}$ & 0.034 & 0.023 & 0.027 & 0.031 & 0.037 & 0.029 & 0.010 & 0.024 & 0.028 & 0.032 \\
\hline Return on Equity ${ }^{a}$ & 0.140 & 0.064 & 0.107 & 0.143 & 0.174 & 0.135 & 0.065 & 0.099 & 0.138 & 0.171 \\
\hline Adequacy Ratio & 0.094 & 0.028 & 0.078 & 0.088 & 0.100 & 0.090 & 0.027 & 0.075 & 0.085 & 0.096 \\
\hline Loan Share & 0.641 & 0.123 & 0.579 & 0.660 & 0.727 & 0.638 & 0.145 & 0.551 & 0.665 & 0.739 \\
\hline Assets in bn. & 54.8 & 113.0 & 0.2 & 5.2 & 57.5 & 108.0 & 200.0 & 0.5 & 8.9 & 75.4 \\
\hline
\end{tabular}

Source: see text.

Bank observation weighted by frequency in the credit contract sample. Number of observation is 611 in the 1998 sample and 1,441 in the 2003 sample. The composition of bank types in the two samples is similar. In 1998, 4.9 percent of the financial institutions that small business owners banked with were credit unions (2003: 3.1 percent), 4.4 percent were thrifts (2003: 4.8 percent), and 90.7 percent were commericial banks (2003: 92.1 percent).

${ }^{a}$ Costs and rates of return are annualized. 


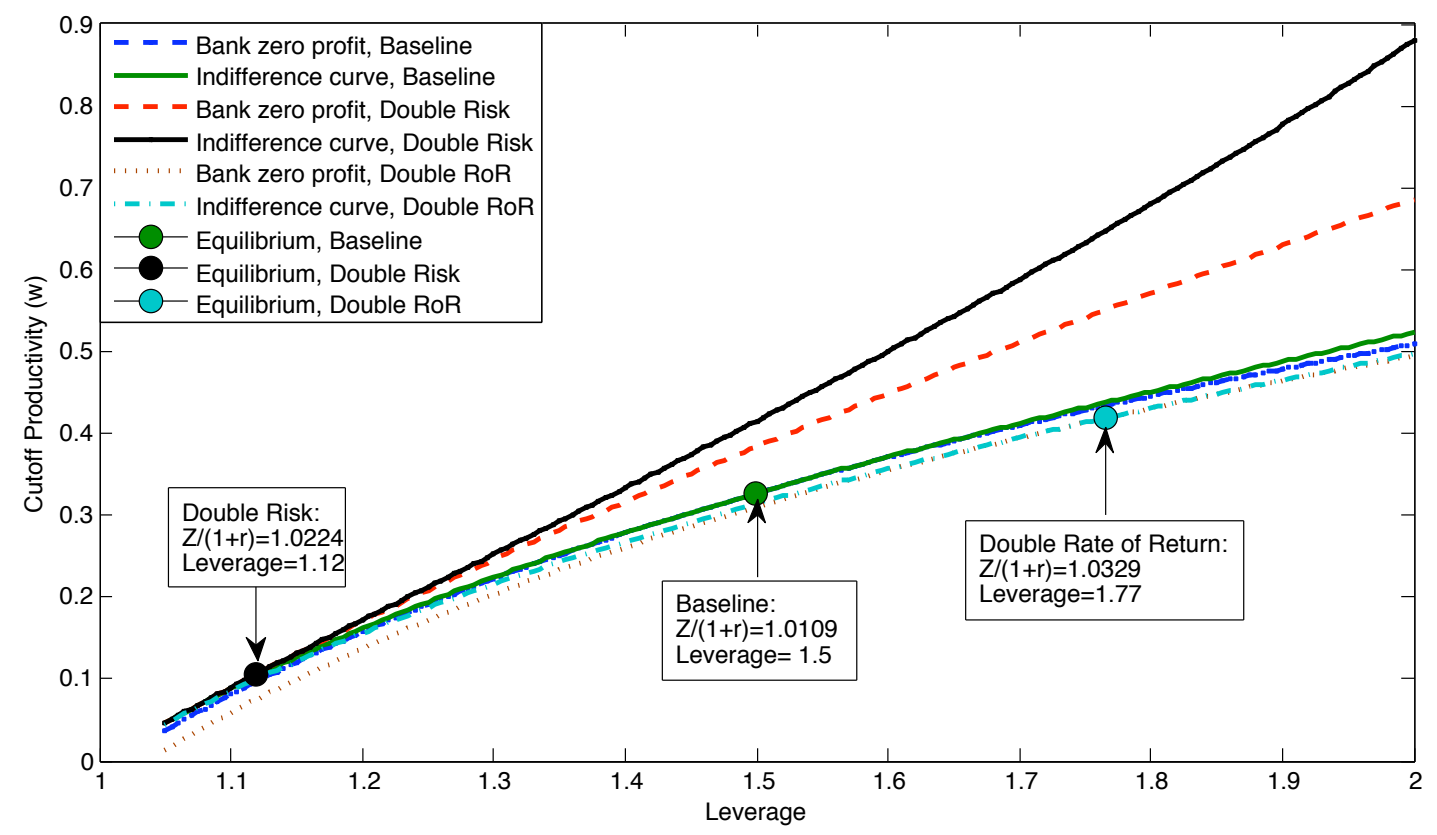

Figure 1: Comparative Statics 
Table 5: Regression Results: Interest Rate

\begin{tabular}{|c|c|c|c|c|c|c|}
\hline & \multicolumn{3}{|c|}{1998} & \multicolumn{3}{|c|}{2003} \\
\hline & OLS & OLS & Selection $^{b}$ & OLS & OLS & Selection $^{b}$ \\
\hline & $(1)$ & $(2)$ & (3) & $(4)$ & $(5)$ & (6) \\
\hline \multicolumn{7}{|c|}{ Firm Variables } \\
\hline Share of Firm's & 0.05 & 0.28 & 0.36 & $0.64^{*}$ & -0.37 & -0.17 \\
\hline Liquid Assets & $(0.23)$ & $(0.27)$ & $(0.37)$ & $(0.26)$ & $(0.30)$ & $(0.31)$ \\
\hline \multirow[t]{2}{*}{ Credit Score } & $-0.13^{\dagger}$ & $-0.17^{\dagger}$ & -0.18 & $-0.24^{* *}$ & $-0.16^{* *}$ & $-0.19^{*}$ \\
\hline & $(0.08)$ & $(0.09)$ & $(0.11)$ & $(0.05)$ & $(0.05)$ & $(0.08)$ \\
\hline Log Number & & -0.13 & -0.15 & & $-0.25^{* *}$ & $-0.25^{* *}$ \\
\hline of Employees & & $(0.10)$ & $(0.11)$ & & $(0.08)$ & $(0.10)$ \\
\hline \multirow[t]{2}{*}{ Log Firm Age } & & -0.10 & -0.09 & & $-0.34^{* *}$ & $-0.42^{* *}$ \\
\hline & & $(0.12)$ & $(0.16)$ & & $(0.10)$ & $(0.15)$ \\
\hline Log Length of & & -0.05 & -0.05 & & $0.27^{* *}$ & $0.32^{* *}$ \\
\hline Relationship & & $(0.05)$ & $(0.06)$ & & $(0.09)$ & $(0.12)$ \\
\hline Net Worth & & $-0.13^{\dagger}$ & $-0.15^{*}$ & & $-0.09^{*}$ & $-0.09^{* *}$ \\
\hline (in mill.) & & $(0.08)$ & $(0.07)$ & & $(0.04)$ & $(0.03)$ \\
\hline \multicolumn{7}{|c|}{ Bank Variables } \\
\hline Interest Cost & $-14.52^{*}$ & $-20.39^{*}$ & $-21.55^{\dagger}$ & $51.05^{* *}$ & 21.49 & 28.81 \\
\hline to Liabilities Ratio & $(7.37)$ & $(8.88)$ & $(12.35)$ & $(13.44)$ & $(18.69)$ & $(28.86)$ \\
\hline Other Cost & 2.85 & 3.96 & 3.67 & 3.37 & -8.67 & -7.67 \\
\hline to Asset Ratio & $(4.14)$ & $(4.62)$ & $(5.12)$ & $(7.20)$ & $(8.12)$ & $(11.16)$ \\
\hline \multirow[t]{2}{*}{ Return on Equity } & -1.01 & -0.31 & 1.68 & 0.28 & 0.56 & 0.95 \\
\hline & $(1.44)$ & $(1.75)$ & $(2.50)$ & $(1.18)$ & $(1.38)$ & $(1.95)$ \\
\hline \multirow[t]{2}{*}{ Adequacy Ratio } & 2.07 & 0.17 & 2.626 & $5.13^{*}$ & 1.28 & 2.09 \\
\hline & $(3.83)$ & $(4.16)$ & $(5.11)$ & $(2.52)$ & $(2.78)$ & $(3.11)$ \\
\hline \multirow[t]{2}{*}{ Log Bank Assets } & & $-0.06^{\dagger}$ & $-0.08^{\dagger}$ & & 0.01 & 0.01 \\
\hline & & $(0.04)$ & $(0.05)$ & & $(0.03)$ & $(0.04)$ \\
\hline \multirow[t]{2}{*}{ Loan Share of Assets } & & -0.42 & -0.32 & & -0.71 & -0.66 \\
\hline & & $(0.84)$ & $(1.15)$ & & $(0.58)$ & $(0.85)$ \\
\hline Additional Controls $^{a}$ & no & yes & yes & no & yes & yes \\
\hline $\mathrm{N}$ & 493 & 493 & 588 & 1,335 & 1,263 & 1,324 \\
\hline Adjusted $R^{2}$ & 0.01 & 0.10 & - & 0.03 & 0.19 & - \\
\hline
\end{tabular}

Significance levels: **1\%, ${ }^{*} 5 \%$, and ${ }^{\dagger} 10 \%$. All observations are weighted with the sample weights in the SSBF.

a Additional controls included are share of nonaccrual loans, share of loans 30-90 days past due, share of loans $>90$ days past d,ue and dummies for bank types (commerical bank, federal savings bank, credit union), market concentration, type of cooperation, judgements against the firm, previous private and firm bankruptcy, region, sector, quarter in which the loans was taken out, urban, female firm owner, minority firm owner, and education of firm owner.

${ }^{b}$ Heckman selection model. Only 81 firm owners report credit denial, hence the model contains only a limited set of variables. The selection equation includes the bank variables, log employment, log firm age, credit score, log length of relationship with bank, a dummy for minority firm owner and quarter in which the loans were taken out, and risk-based capital ratio. Note that the risk-based capital ratio is not available for credit unions (22 obs.). Using the risk-based net worth to proxy for the risk-based capital ratio does not change the results reported in columns (3) and (6) significantly. 
Table 6: Regression Results Credit Amount

\begin{tabular}{|c|c|c|c|c|c|c|}
\hline & \multicolumn{3}{|c|}{1998 Sample } & \multicolumn{3}{|c|}{2003 Sample } \\
\hline & OLS & OLS & Selection $^{a}$ & OLS & OLS & Selection $^{a}$ \\
\hline \multirow[t]{2}{*}{ Net Worth } & $0.320^{* *}$ & $0.298^{* *}$ & $0.318^{* *}$ & $0.360^{* *}$ & $0.334^{* *}$ & $0.318^{* *}$ \\
\hline & $(0.084)$ & $(0.083)$ & $(0.077)$ & $(0.055)$ & $(0.057)$ & $(0.055)$ \\
\hline Ln Number & & $0.066^{*}$ & & & $0.139^{* *}$ & \\
\hline of Employees & & $(0.028)$ & & & $(0.032)$ & \\
\hline Controls & no & no & no & no & no & no \\
\hline $\mathrm{N}$ & 711 & 711 & 959 & 1,693 & 1,693 & 1,856 \\
\hline $\mathrm{R}^{2}$ & 0.29 & 0.30 & - & 0.27 & 0.28 & - \\
\hline
\end{tabular}

Significance levels: $* 5 \% \quad * * 1 \%$ All observations are weighted with the sample weights in the SSBF.

${ }^{a}$ Heckman selection model using information on whether the firm's credit application was accepted. The probability of receiving credit is estimated using net worth, $\ln ($ employment), $\ln$ (length of relationship with the lender), ln(firmage), credit score, and dummy variables for industry, region, gender, minority status, organizational form of the firm, previous bankruptcies and judgements against the firm. 
Table 7: Regression Results: Credit Amount

\begin{tabular}{|c|c|c|c|c|c|c|}
\hline & \multicolumn{3}{|c|}{1998 Sample } & \multicolumn{3}{|c|}{2003 Sample } \\
\hline & $\begin{array}{c}\text { OLS } \\
(1)\end{array}$ & $\begin{array}{c}\text { OLS } \\
(2) \\
\end{array}$ & $\begin{array}{c}\text { Selection }^{c} \\
(3)\end{array}$ & $\begin{array}{c}\text { OLS } \\
(4)\end{array}$ & $\begin{array}{c}\text { OLS } \\
(5) \\
\end{array}$ & $\begin{array}{c}\text { Selection }^{c} \\
(6)\end{array}$ \\
\hline \multicolumn{7}{|c|}{ Firm Variables } \\
\hline Net Worth & $0.320^{* *}$ & $0.259^{* *}$ & $0.259^{* *}$ & $0.360^{* *}$ & $0.302^{* *}$ & $0.302^{* *}$ \\
\hline (in mill.) & $(0.084)$ & $(0.024)$ & $(0.077)$ & $(0.055)$ & $(0.018)$ & $(0.081)$ \\
\hline Share of Firm's & & $0.168^{*}$ & $0.168^{* *}$ & & $-0.509^{* *}$ & $-0.491^{* *}$ \\
\hline Liquid Assets & & $(0.085)$ & $(0.062)$ & & $(0.155)$ & $(0.154)$ \\
\hline Log Number & & $0.068^{*}$ & $0.062^{\dagger}$ & & $0.122^{* *}$ & $0.120^{*}$ \\
\hline of Employees & & $(0.031)$ & $(0.032)$ & & $(0.040)$ & $(0.051)$ \\
\hline \multirow[t]{2}{*}{ Log Firm Age } & & -0.011 & -0.011 & & -0.034 & -0.055 \\
\hline & & $(0.038)$ & $(0.028)$ & & $(0.051)$ & $(0.045)$ \\
\hline Log Length of & & -0.027 & -0.033 & & 0.001 & 0.010 \\
\hline Relationship & & $(0.017)$ & $(0.021)$ & & $(0.041)$ & $(0.033)$ \\
\hline \multirow[t]{2}{*}{ Credit Score } & & $0.070^{* *}$ & $0.073^{*}$ & & -0.023 & -0.030 \\
\hline & & $(0.027)$ & $(0.034)$ & & $(0.028)$ & $(0.021)$ \\
\hline \multicolumn{7}{|c|}{ Bank Variables } \\
\hline Interest Cost & & -0.222 & 2.027 & & -0.545 & 2.032 \\
\hline to Liabilities Ratio & & $(2.858)$ & $(1.914)$ & & $(9.438)$ & $(5.894)$ \\
\hline Other Cost & & -1.865 & -0.710 & & -3.556 & -4.275 \\
\hline to Asset Ratio & & $(1.436)$ & $(0.599)$ & & $(4.212)$ & $(3.472)$ \\
\hline \multirow[t]{2}{*}{ Return on Equity } & & -0.748 & -1.227 & & 0.462 & 0.489 \\
\hline & & $(0.552)$ & $(0.848)$ & & $(0.702)$ & $(0.504)$ \\
\hline \multirow[t]{2}{*}{ Adequacy Ratio } & & -0.937 & -1.412 & & 0.569 & 0.293 \\
\hline & & $(1.300)$ & $(0.932)$ & & $(1.413)$ & $(0.845)$ \\
\hline \multirow[t]{2}{*}{ Log Bank Assets } & & 0.010 & 0.007 & & 0.022 & $0.022^{\dagger}$ \\
\hline & & $(0.011)$ & $(0.007)$ & & $(0.016)$ & $(0.014)$ \\
\hline \multirow[t]{2}{*}{ Loan Share of Assets } & & 0.054 & 0.109 & & 0.168 & 0.091 \\
\hline & & $(0.272)$ & $(0.198)$ & & $(0.298)$ & $(0.231)$ \\
\hline Additional Controls $^{a, b}$ & no & yes & yes & no & yes & yes \\
\hline $\mathrm{N}$ & 711 & 493 & 588 & 1,693 & 1,263 & 1,324 \\
\hline Adjusted $R^{2}$ & 0.23 & 0.26 & - & 0.27 & 0.25 & - \\
\hline
\end{tabular}

Significance levels: $* * 1 \%,{ }^{*} 5 \%$, and ${ }^{\dagger} 10 \%$. All observations are weighted with the sample weights in the SSBF.

$a$ Additional controls included in columns (2) and (5) are share of nonaccrual loans, share of loans 30-90 days past due, share of loans > 90 days past due, and dummies for bank types (commerical bank, federal savings bank, credit union), market concentration, type of cooperation, judgements against the firm, previous private and firm bankruptcy, region, sector, quarter in which the loans were taken out, urban, female firm owner, minority firm owner, and education of firm owner.

${ }^{b}$ Additional controls included in columns (3) and (6) are dummies for bank types, market concentration, type of cooperation, region, sector, quarter in which the loans were taken out, and urban.

${ }^{c}$ Heckman selection model. The selection equation includes the bank variables, log employment, log firm age, credit score, log length of relationship with bank, a dummy for minority firm owner, net worth, quarterly dummies, sectoral dummies, and risk-based capital ratio. Note that the risk-based capital ratio is not available for credit unions (22 obs.). Using the risk-based net worth to proxy for the risk-based capital ratio does not change the results reported in columns (3) and (6) significantly. 
Table 8: Firm Characteristics by Bank Size

\begin{tabular}{|c|c|c|c|c|c|}
\hline & \multicolumn{2}{|c|}{ Small Banks } & \multicolumn{2}{|c|}{ Large Banks } & \multirow[t]{2}{*}{ Difference } \\
\hline & mean & std & mean & std & \\
\hline & \multicolumn{5}{|c|}{1998 Sample } \\
\hline Number of Employees & 14.20 & 32.65 & 14.03 & 28.46 & -0.17 \\
\hline Firm Age & 12.71 & 8.83 & 11.35 & 10.35 & -1.34 \\
\hline Length of Lending Relationship & 8.22 & 8.55 & 5.43 & 7.15 & $-2.80^{* *}$ \\
\hline Credit Score $^{a}$ & 3.10 & 1.10 & 2.91 & 1.04 & $-0.19^{\dagger}$ \\
\hline Share in Manufacturing & 0.10 & 0.30 & 0.08 & 0.27 & -0.03 \\
\hline Net Worth (in mill.) & 0.41 & 1.09 & 0.53 & 1.60 & 0.12 \\
\hline \multirow[t]{2}{*}{$\mathrm{N}$} & \multicolumn{2}{|c|}{379} & \multicolumn{2}{|c|}{144} & \\
\hline & \multicolumn{5}{|c|}{2003 Sample } \\
\hline Number of Employees & 15.37 & 30.89 & 17.07 & 36.35 & 1.70 \\
\hline Firm Age & 15.76 & 11.96 & 15.96 & 10.08 & 0.20 \\
\hline Length of Lending Relationship & 10.18 & 9.25 & 11.03 & 9.18 & 0.85 \\
\hline Credit Score $^{a}$ & 3.83 & 1.43 & 3.77 & 1.47 & -0.05 \\
\hline Share in Manufacturing & 0.09 & 0.28 & 0.15 & 0.35 & $0.06^{* *}$ \\
\hline Net Worth (in mill.) & 0.70 & 2.02 & 0.95 & 2.43 & $0.15^{*}$ \\
\hline $\mathrm{N}$ & \multicolumn{2}{|c|}{928} & \multicolumn{2}{|c|}{412} & \\
\hline
\end{tabular}

Significance levels: ${ }^{* *} 1 \%,{ }^{*} 5 \%$, and ${ }^{\dagger} 10 \%$. Firms that received credit only.

$a$ The credit score in 1998 goes from 1 (lowest) to 5 (highest) and in 2003 from 1 (lowest) to 6 (highest). 
Table 9: Regression Results: Credit Amount by Bank Size

\begin{tabular}{|c|c|c|c|c|}
\hline & \multicolumn{2}{|c|}{1998 Sample } & \multicolumn{2}{|c|}{2003 Sample } \\
\hline & $\begin{array}{c}\text { Small Banks } \\
<\$ 50 \text { bn. assets } \\
(1)\end{array}$ & $\begin{array}{c}\text { Large Banks } \\
\geq \$ 50 \text { bn. assets } \\
(2)\end{array}$ & $\begin{array}{c}\text { Small Banks } \\
<\$ 50 \text { bn. assets } \\
(3)\end{array}$ & $\begin{array}{c}\text { Large Banks } \\
\geq \$ 50 \text { bn. assets } \\
(4)\end{array}$ \\
\hline \multicolumn{5}{|c|}{ Firm Variables } \\
\hline Net Worth & $0.365^{* *}$ & $0.147^{*}$ & $0.296^{* *}$ & $0.298^{* *}$ \\
\hline (in mill.) & $(0.028)$ & $(0.066)$ & $(0.018)$ & $(0.045)$ \\
\hline Share of Firm's & 0.158 & 0.216 & $-0.531^{* *}$ & -0.572 \\
\hline Liquid Assets & $(0.088)$ & $(0.328)$ & $(0.148)$ & $(0.478)$ \\
\hline Log Number & $0.061^{\dagger}$ & $0.290^{*}$ & $0.096^{*}$ & $0.210^{\dagger}$ \\
\hline of Employees & $(0.033)$ & $(0.118)$ & $(0.040)$ & $(0.112)$ \\
\hline \multirow[t]{2}{*}{ Log Firm Age } & 0.033 & $-0.314^{\dagger}$ & -0.061 & 0.053 \\
\hline & $(0.041)$ & $(0.183)$ & $(0.048)$ & $(0.168)$ \\
\hline Log Length of & $-0.059^{* *}$ & 0.007 & 0.020 & 0.090 \\
\hline Relationship & $(0.019)$ & $(0.064)$ & $(0.044)$ & $(0.143)$ \\
\hline \multirow[t]{2}{*}{ Credit Score } & $0.063^{*}$ & 0.044 & -0.036 & -0.010 \\
\hline & $(0.028)$ & $(0.129)$ & $(0.029)$ & $(0.080)$ \\
\hline \multicolumn{5}{|c|}{ Bank Variables } \\
\hline Interest Cost & $9.320^{\dagger}$ & -31.337 & 2.797 & -45.694 \\
\hline to Liabilities Ratio & $(5.452)$ & $(26.754)$ & $(8.861)$ & $(58.453)$ \\
\hline Other Cost & -1.620 & -7.234 & -3.665 & 0.223 \\
\hline to Asset Ratio & $(1.322)$ & $(28.268)$ & $(3.535)$ & $(15.570)$ \\
\hline \multirow[t]{2}{*}{ Return on Equity } & -0.873 & -1.144 & 0.744 & -3.082 \\
\hline & $(0.527)$ & $(6.363)$ & $(0.633)$ & $(2.875)$ \\
\hline \multirow[t]{2}{*}{ Adequacy Ratio } & -0.370 & 5.447 & 0.805 & -7.406 \\
\hline & $(1.296$ & $(13.071)$ & $(1.284)$ & $(6.121)$ \\
\hline \multirow[t]{2}{*}{ Log Bank Assets } & 0.014 & 0.105 & $0.040^{*}$ & -0.197 \\
\hline & $(0.016)$ & $(0.381)$ & $(0.020)$ & $(0.187)$ \\
\hline \multirow[t]{2}{*}{ Loan Share of Assets } & -0.144 & -2.169 & 0.219 & -0.763 \\
\hline & $(0.316)$ & $(2.086)$ & $(0.315)$ & $(1.602)$ \\
\hline Additional Controls ${ }^{a}$ & yes & yes & yes & yes \\
\hline $\mathrm{N}$ & 379 & 114 & 877 & 386 \\
\hline Adjusted $R^{2}$ & 0.42 & -0.28 & 0.32 & 0.12 \\
\hline
\end{tabular}

Significance levels: ${ }^{* *} 1 \%,{ }^{*} 5 \%$, and ${ }^{\dagger} 10 \%$. All observations are weighted with the sample weights in the SSBF.

$a$ Additional controls included are share of nonaccrual loans, share of loans 30-90 days past due, share of loans $>90$ days past due, and dummies for bank types (commerical bank, federal savings bank, credit union), market concentration, type of cooperation, judgements against the firm, previous private and firm bankruptcy, region, sector, quarter in which the loans were taken out, urban, female firm owner, minority firm owner, and education of firm owner. 
Table 10: Regression Results: Interest Rate by Bank Size - 1998 Sample

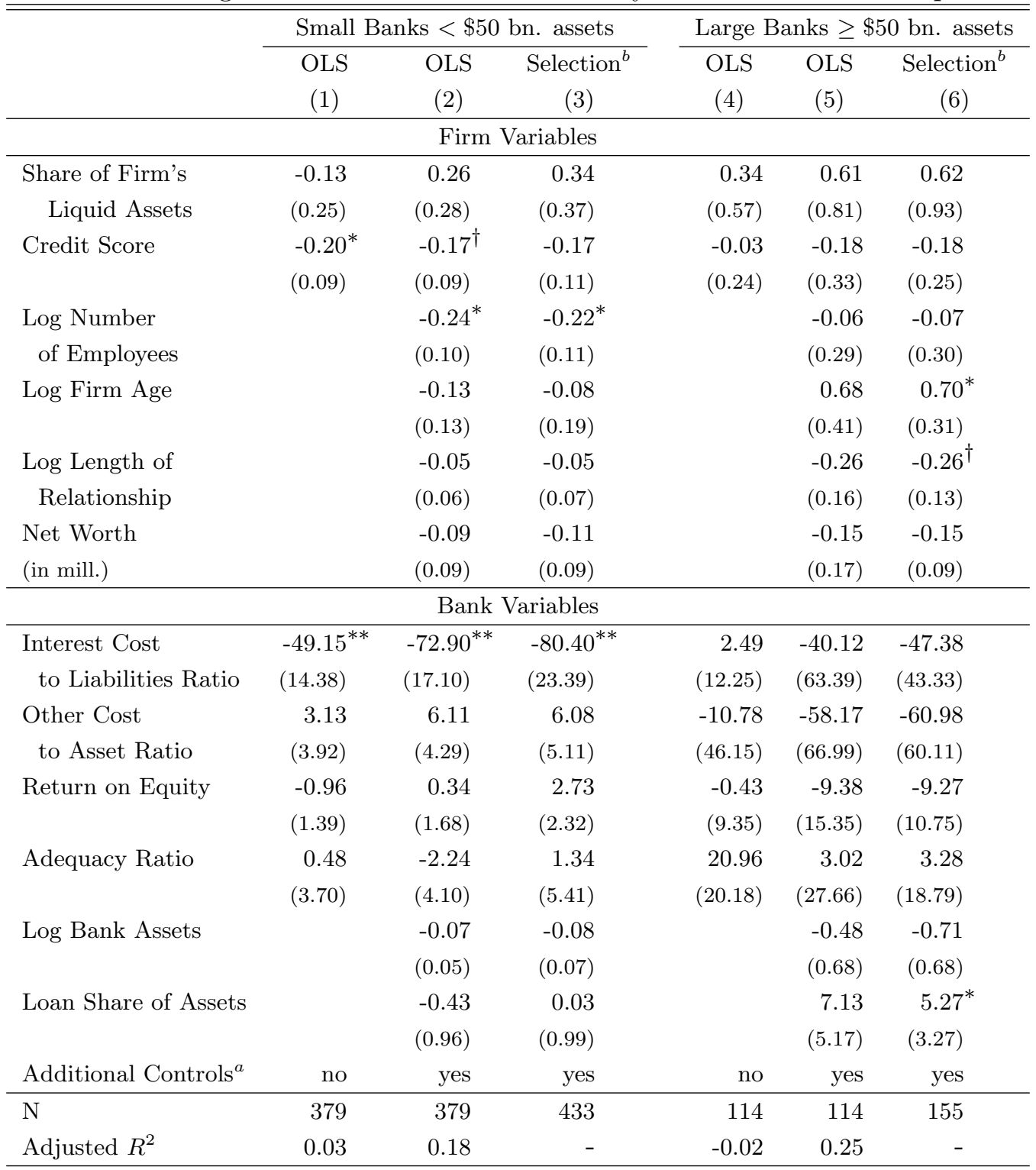

Significance levels: ${ }^{* *} 1 \%,{ }^{*} 5 \%$, and ${ }^{\dagger} 10 \%$. All observations are weighted with the sample weights in the SSBF.

$a$ Additional controls included are share of nonaccrual loans, share of loans 30-90 days past due, share of loans $>90$ days past due, and dummies for bank types (commerical bank, federal savings bank, credit union), market concentration, type of cooperation, judgements against the firm, previous private and firm bankruptcy, region, sector, quarter in which the loans were taken out, urban, female firm owner, minority firm owner, and education of firm owner.

${ }^{b}$ Heckman selection model. Additional controls included are share of nonaccrual loans, share of loans 30-90 days past due, share of loans $>90$ days past due, and dummies for bank types (commerical bank, federal savings bank, credit union), market concentration, type of cooperation, urban, region, sector, and quarter in which the loans were taken out. The selection equation includes the bank variables, log employment, log firm age, credit score, log length of relationship with bank, a dummy for minority firm owner, net worth, sectoral dummies, and risk-based capital ratio. Note that the risk-based capital ratio is not available for credit unions. 
Table 11: Regression Results: Interest Rate by Bank Size - 2003 Sample

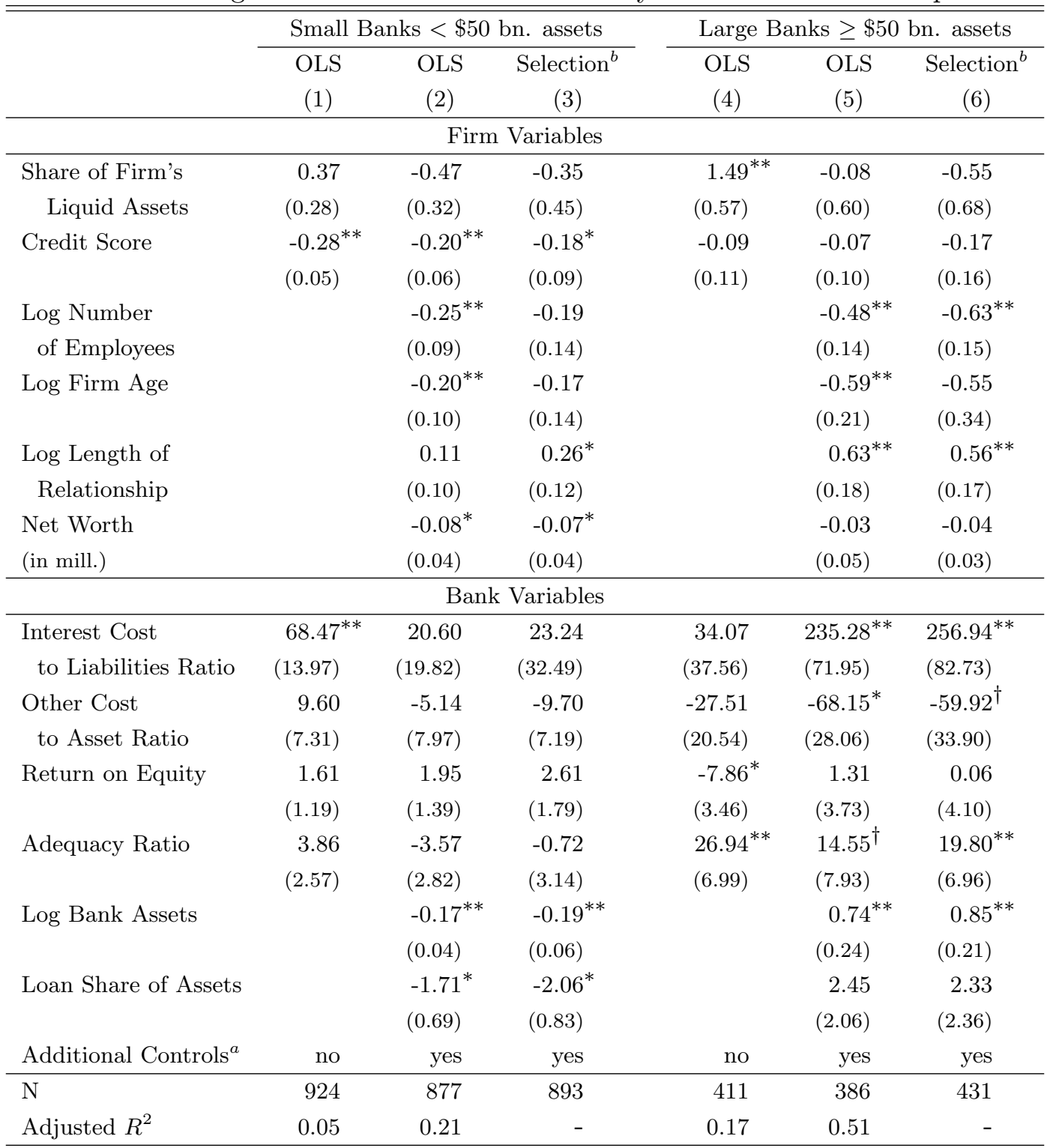

Significance levels: ${ }^{* *} 1 \%, * 5 \%$, and ${ }^{\dagger} 10 \%$. All observations are weighted with the sample weights in the SSBF.

${ }^{a}$ Additional controls included are share of nonaccrual loans, share of loans 30-90 days past due, share of loans $>90$ days past due, and dummies for bank types (commerical bank, federal savings bank, credit union), market concentration, type of cooperation, judgements against the firm, previous private and firm bankruptcy, region, sector, quarter in which the loans were taken out, urban, female firm owner, minority firm owner, and education of firm owner.

${ }^{b}$ Heckman selection model. Additional controls included are share of nonaccrual loans, share of loans 30-90 days past due, share of loans $>90$ days past due, and dummies for bank types (commerical bank, federal savings bank, credit union), market concentration, type of cooperation, urban, region, sector, and quarter in which the loans were taken out. The selection equation includes the bank variables, log employment, log firm age, credit score, log length of relationship with bank, a dummy for minority firm owner, net worth, sectoral dummies, and risk-based capital ratio. Note that the risk-based capital ratio is not available for credit unions (22 obs.). Using the risk-based net worth to proxy for the risk-based capital ratio does not change the results reported in columns (3) and (6) significantly. 
Table 12: Dependent Variable: Credit Amount

\begin{tabular}{|c|c|c|c|c|c|c|}
\hline & \multicolumn{3}{|c|}{1998 Sample } & \multicolumn{3}{|c|}{2003 Sample } \\
\hline & OLS & OLS & Selection $^{a}$ & OLS & OLS & Selection $^{a}$ \\
\hline \multirow[t]{2}{*}{ Net Worth $^{b}$} & $0.225^{*}$ & $0.316^{* *}$ & $0.224^{*}$ & $0.325^{* *}$ & $0.264^{*}$ & $0.284^{*}$ \\
\hline & $(0.099)$ & $(0.118)$ & $(0.099)$ & $(0.121)$ & $(0.119)$ & $(0.117)$ \\
\hline Ln Number & & $0.136^{* *}$ & & & $0.306^{* *}$ & \\
\hline of Employees & & $(0.040)$ & & & $(0.043)$ & \\
\hline Controls $^{c}$ & no & yes & no & no & yes & no \\
\hline $\mathrm{N}$ & 542 & 542 & 876 & 1,693 & 1,652 & 1,829 \\
\hline $\mathrm{R}^{2}$ & 0.16 & 0.16 & - & 0.07 & 0.12 & - \\
\hline
\end{tabular}

Significance levels: $\quad * 5 \% \quad * * 1 \%$. All observations are weighted with the sample weights in the SSBF.

${ }^{a}$ Heckman selection model using information on whether the firm's credit application was accepted. The probability of receiving credit is estimated using net worth, $\ln$ (employment), $\ln$ (length of relationship with the lender), $\ln$ (firmage), credit score, and dummy variables for industry, region, gender, minority status, organizational form of the firm, previous bankruptcies, and judgements against the firm.

${ }^{b}$ Net worth is defined as the sum of land, depreciable assets, and the net value of the private residence minus loans.

${ }^{c}$ Additional controls include $\ln$ (firmage), credit score, and dummy variables for industry, region, gender, minority status, organizational form of the firm, previous bankruptcies, and judgements against the firm.

Table 13: Dependent Variable: Credit Amount

\begin{tabular}{|c|c|c|c|c|c|c|}
\hline & \multicolumn{3}{|c|}{1998 Sample } & \multicolumn{3}{|c|}{2003 Sample } \\
\hline & OLS & OLS & Selection $^{a}$ & OLS & OLS & Selection $^{a}$ \\
\hline \multirow[t]{2}{*}{ Net Worth ${ }^{b}$} & $0.179^{\dagger}$ & $0.325^{*}$ & $0.196^{\dagger}$ & $0.227^{*}$ & $0.168^{\dagger}$ & 0.177 \\
\hline & $(0.117)$ & $(0.138)$ & $(0.116)$ & $(0.108)$ & $(0.119)$ & $(0.097)$ \\
\hline Ln Number & & $0.154^{* *}$ & & & $0.335^{* *}$ & \\
\hline of Employees & & $(0.039)$ & & & $(0.041)$ & \\
\hline controls $^{c}$ & no & yes & no & no & yes & no \\
\hline $\mathrm{N}$ & 711 & 542 & 876 & 1,693 & 1,652 & 1,29 \\
\hline $\mathrm{R}^{2}$ & 0.02 & 0.13 & - & 0.07 & 0.08 & - \\
\hline
\end{tabular}

Significance levels: $\dagger 10 \% \quad * 5 \% \quad * * 1 \%$. All observations are weighted with the sample weights in the SSBF.

${ }^{a}$ Heckman selection model using information on whether the firm's credit application was accepted. The probability of receiving credit is estimated using net worth, $\ln$ (employment), $\ln$ (length of relationship with the lender), ln(firmage), credit score, and dummy variables for industry, region, gender, minority status, organizational form of the firm, previous bankruptcies, and judgements against the firm.

${ }^{b}$ Net worth is defined as the sum of land, depreciable assets, and the net value of the private residence minus all liabilities.

${ }^{c}$ Additional controls include $\ln$ (firmage), credit score, and dummy variables for industry, region, gender, minority status, organizational form of the firm, previous bankruptcies, and judgements against the firm. 
Table 14: Dependent Variable: Credit Amount

\begin{tabular}{|c|c|c|c|c|c|c|}
\hline & \multicolumn{3}{|c|}{1998 Sample } & \multicolumn{3}{|c|}{2003 Sample } \\
\hline & OLS & OLS & Selection $^{a}$ & OLS & OLS & Selection $^{a}$ \\
\hline \multirow[t]{2}{*}{ Net Worth ${ }^{b}$} & $0.373^{* *}$ & $0.341^{* *}$ & $0.372^{* *}$ & $0.395^{* *}$ & $0.365^{* *}$ & $0.392^{* *}$ \\
\hline & $(0.078)$ & $(0.109)$ & $(0.078)$ & $(0.056)$ & $(0.056)$ & $(0.056)$ \\
\hline Ln Number & & 0.052 & & & $0.176^{* *}$ & \\
\hline of Employees & & $(0.034)$ & & & $(0.033)$ & \\
\hline controls $^{c}$ & no & yes & no & no & yes & no \\
\hline $\mathrm{N}$ & 711 & 542 & 876 & 1,693 & 1,652 & 1,829 \\
\hline $\mathrm{R}^{2}$ & 0.32 & 0.35 & - & 0.27 & 0.28 & - \\
\hline
\end{tabular}

Significance levels: : $\quad * 5 \% \quad * * 1 \%$. All observations are weighted with the sample weights in the SSBF

${ }^{a}$ Heckman selection model using information on whether the firm's credit application was accepted. The probability of receiving credit is estimated using net worth, $\ln$ (employment), $\ln$ (length of relationship with the lender), $\ln ($ firmage), credit score, and dummy variables for industry, region, gender, minority status, organizational form of the firm, previous bankruptcies, and judgements against the firm.

${ }^{b}$ Net worth is defined as all firm assets minus all firm liabilities.

${ }^{c}$ Additional controls include $\ln$ (firmage), credit score, and dummy variables for industry, region, gender, minority status, organizational form of the firm, previous bankruptcies, and judgements against the firm. 
Table 15: Dependent Variable: Interest Rate - Alternative Measures 2003 Sample

\begin{tabular}{|c|c|c|c|c|c|c|}
\hline & \multicolumn{3}{|c|}{ Alternative Cost Measure } & \multicolumn{3}{|c|}{ Three-Year Averages } \\
\hline & OLS & OLS & Selection $^{b}$ & OLS & OLS & Selection $^{b}$ \\
\hline & $(1)$ & $(2)$ & (3) & $(4)$ & $(5)$ & $(6)$ \\
\hline \multicolumn{7}{|c|}{ Firm Variables } \\
\hline Share of Firm's & $0.66^{*}$ & -0.38 & -0.19 & $0.69^{* *}$ & -0.38 & -0.14 \\
\hline Liquid Assets & $(0.26)$ & $(0.29)$ & $(0.37)$ & $(0.26)$ & $(0.30)$ & $(0.38)$ \\
\hline \multirow[t]{2}{*}{ Credit Score } & $-0.24^{* *}$ & $-0.15^{* *}$ & $-0.18^{*}$ & $-0.23^{* *}$ & $-0.15^{* *}$ & $-0.16^{*}$ \\
\hline & $(0.05)$ & $(0.05)$ & $(0.07)$ & $(0.05)$ & $(0.05)$ & $(0.07)$ \\
\hline Log Number & & $-0.24^{* *}$ & $-0.23^{*}$ & & $-0.25^{* *}$ & $-0.29^{* *}$ \\
\hline of Employees & & $(0.08)$ & $(0.09)$ & & $(0.08)$ & $(0.10)$ \\
\hline \multirow[t]{2}{*}{ Log Firm Age } & & $-0.24^{* *}$ & $-0.44^{* *}$ & & $-0.33^{* *}$ & $-0.40^{* *}$ \\
\hline & & $(0.08)$ & $(0.14)$ & & $(0.10)$ & $(0.14)$ \\
\hline Log Length of & & $0.30^{* *}$ & $0.34^{* *}$ & & $0.27^{* *}$ & 0.27 \\
\hline Relationship & & $(0.09)$ & $(0.12)$ & & $(0.09)$ & $(0.35)$ \\
\hline Net Worth & & $-0.09^{* *}$ & $-0.09^{* *}$ & & $-0.09^{*}$ & $-0.09^{* *}$ \\
\hline (in mill.) & & $(0.03)$ & $(0.03)$ & & $(0.03)$ & $(0.03)$ \\
\hline \multicolumn{7}{|c|}{ Bank Variables } \\
\hline Interest Cost & $51.78^{* *}$ & 22.36 & 30.33 & 25.07 & $33.29^{\dagger}$ & 32.08 \\
\hline to Liabilities Ratio & $(13.46)$ & $(17.54)$ & $(27.94)$ & $(15.31)$ & $(18.22)$ & $(17.10)$ \\
\hline Other Cost & -5.51 & $-40.77^{* *}$ & $-37.61^{*}$ & 3.41 & -13.28 & -10.65 \\
\hline to Asset Ratio & $(13.27)$ & $(13.77)$ & $(17.49)$ & $(7.79)$ & $(8.41)$ & $(16.88)$ \\
\hline \multirow[t]{2}{*}{ Return on Equity } & 0.32 & 0.14 & 0.58 & -0.19 & -0.28 & -0.33 \\
\hline & $(1.18)$ & $(1.31)$ & $(1.83)$ & $(1.33)$ & $(1.43)$ & $(2.69)$ \\
\hline \multirow[t]{2}{*}{ Adequacy Ratio } & $5.36^{*}$ & -0.50 & 0.44 & $7.48^{* *}$ & -1.13 & -1.75 \\
\hline & $(2.51)$ & $(2.63)$ & $(3.21)$ & $(2.90)$ & $(3.24)$ & $(4.03)$ \\
\hline \multirow[t]{2}{*}{ Log Bank Assets } & & -0.03 & -0.03 & & 0.01 & -0.00 \\
\hline & & $(0.03)$ & $(0.04)$ & & $(0.03)$ & $(0.04)$ \\
\hline \multirow[t]{2}{*}{ Loan Share of Assets } & & $-1.19^{*}$ & -1.11 & & -0.36 & -0.36 \\
\hline & & $(0.55)$ & $(0.80)$ & & $(0.61)$ & $(0.91)$ \\
\hline Additional Controls ${ }^{a}$ & no & yes & yes & no & yes & yes \\
\hline $\mathrm{N}$ & 1,335 & 1,263 & 1,324 & 1,338 & 1,266 & 1,338 \\
\hline Adjusted $R^{2}$ & 0.03 & 0.25 & - & 0.02 & 0.21 & - \\
\hline
\end{tabular}

Significance levels: ${ }^{* *} 1 \%,{ }^{*} 5 \%$, and ${ }^{\dagger} 10 \%$. All observations are weighted with the sample weights in the SSBF.

$a$ Additional controls included are share of nonaccrual loans, share of loans 30-90 days past due, share of loans $>90$ days past due, and dummies for bank types (commerical bank, federal savings bank, credit union), market concentration, type of cooperation, judgements against the firm, previous private and firm bankruptcy, region, sector, quarter in which the loans were taken out, urban, female firm owner, minority firm owner, and education of firm owner.

${ }^{b}$ Heckman selection model. Only 81 firm owners report credit denial, hence the model contains only a limited set of variables. The selection equation includes the bank variables, log employment, log firm age, credit score, log length of relationship with bank, a dummy for minority firm owner and quarter in which the loans were taken out, and risk-based capital ratio. Note that the risk-based capital ratio is not available for credit unions (23 obs.). Using the risk-based net worth to proxy for the risk-based capital ratio does not change the results reported in columns (3) and (6) significantly. 

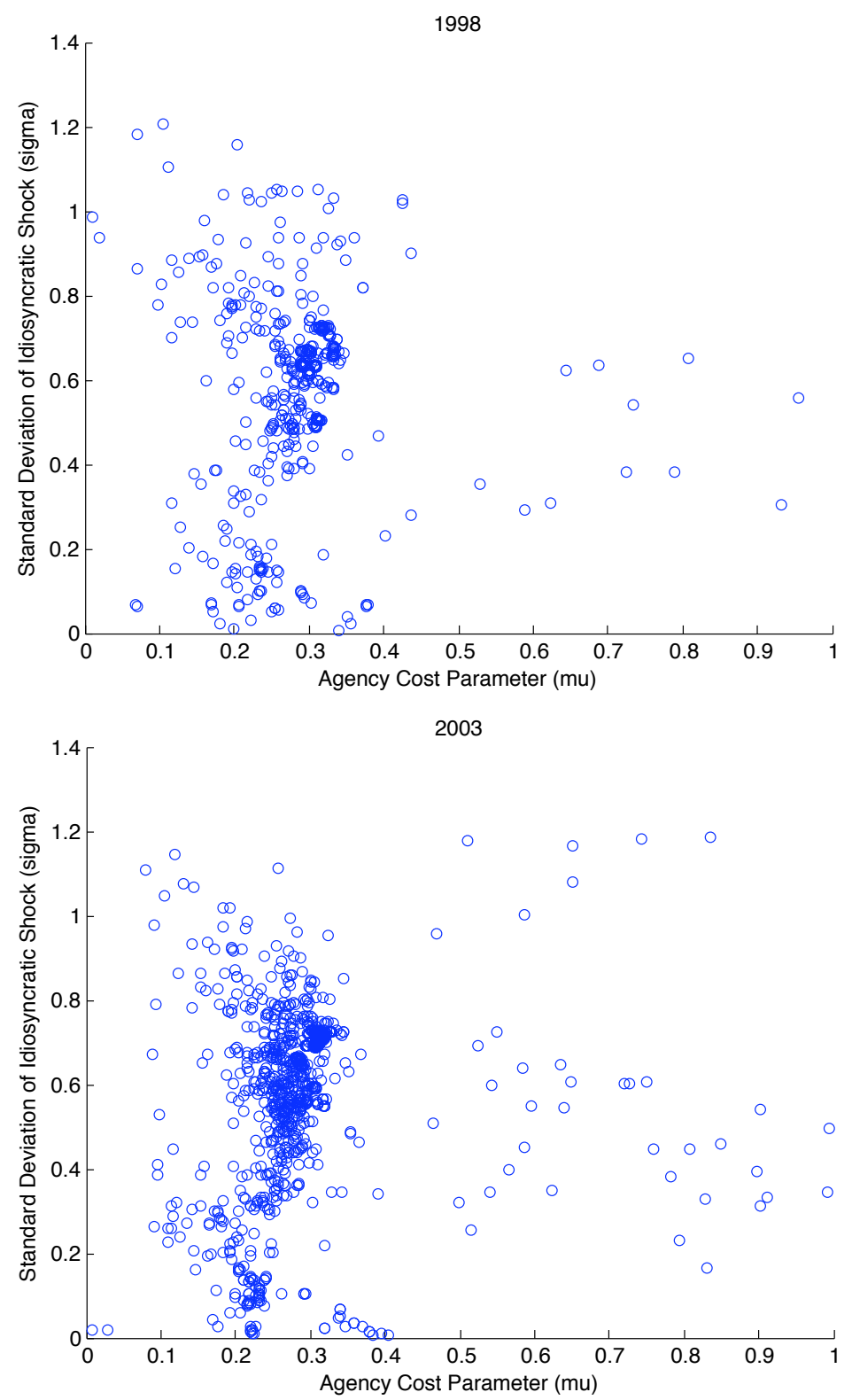

Figure 2: CSV Implied Agency Cost and Risk Parameters 

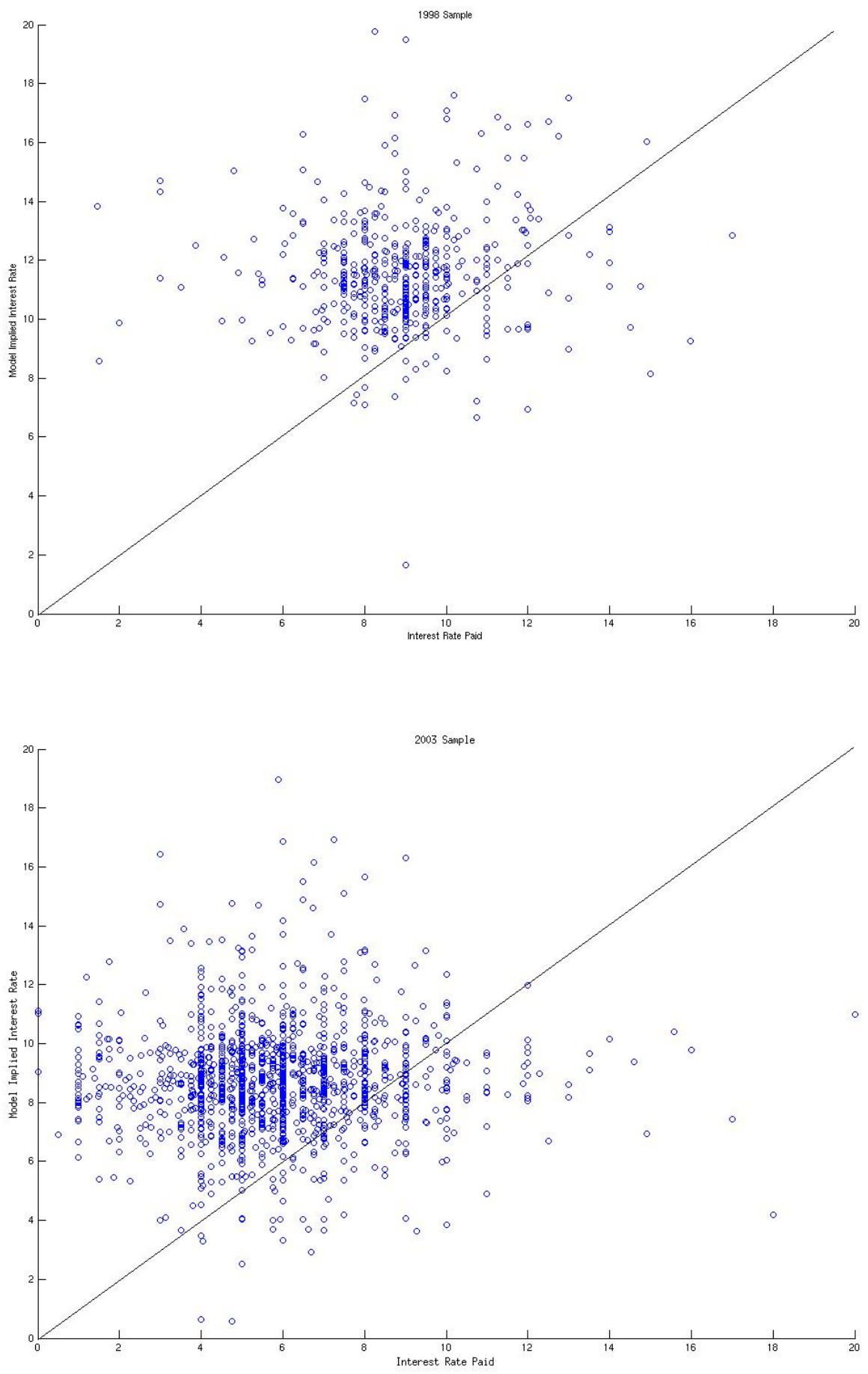

Figure 3: MH Implied Interest Rates and Actual Interest Rates 

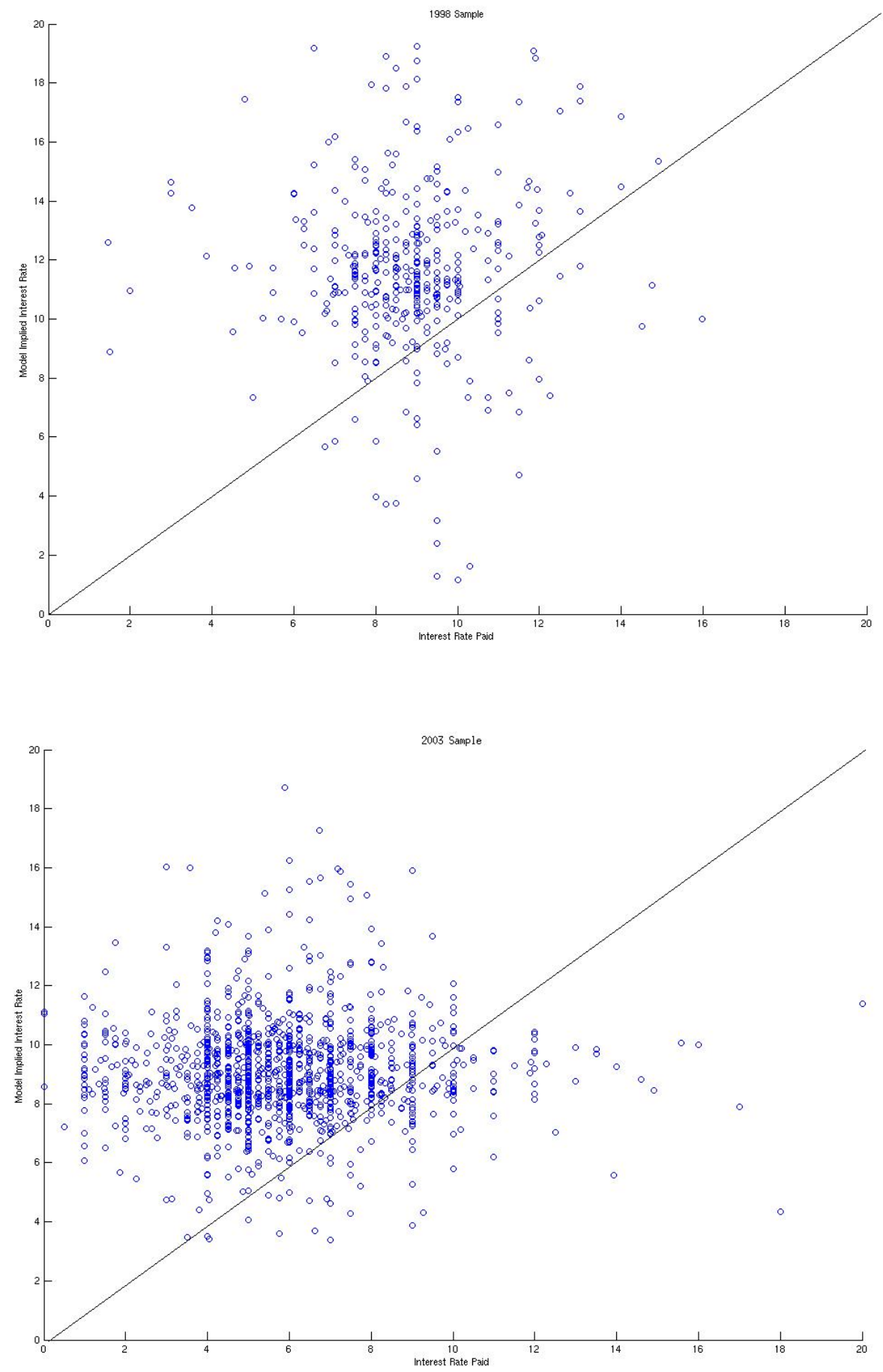

Figure 4: $\mathrm{MH}$ and Actual Interest Rates, Quarterly Averages. 


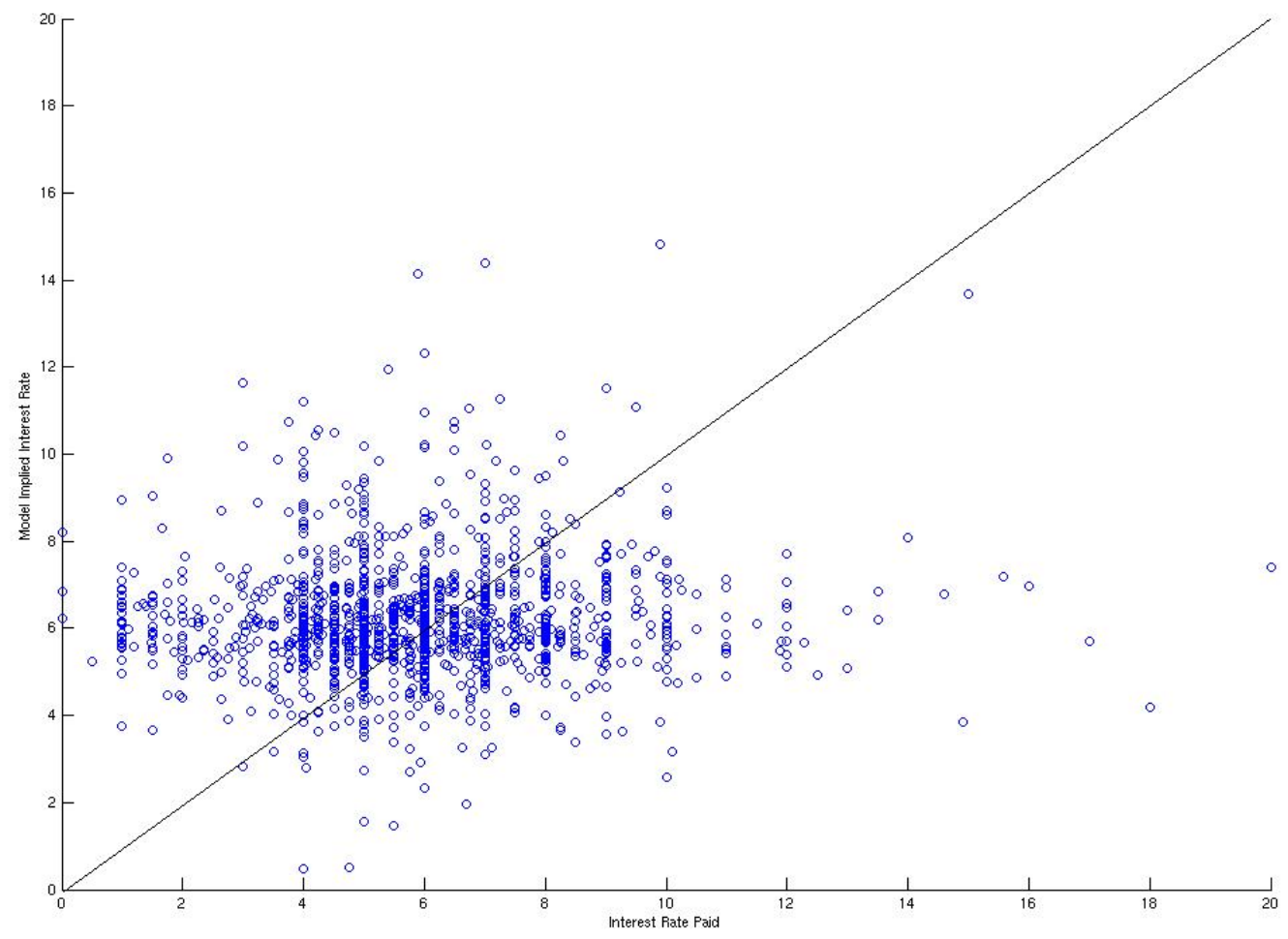

Figure 5: MH and Actual Interest Rates, Alternative Cost Measure — 2003 Sample 